\title{
Mealworm (Tenebrio molitor) potencial in fish nutrition: a review
}

\author{
Potencial da larva da farinha (Tenebrio molitor) na nutrição de peixes: uma revisão \\ Potencial de las larvas de harina (Tenebrio molitor) en la nutrición de los peces: una revisión
}

\begin{abstract}
The creation of aquatic organisms it is constantly growing and with this comes the need to meet this demand with the increased production of inputs such as feed for aquaculture. Fish nutrition is mainly characterized by the use of fish meal and oil for the manufacture of rations for their food. Soybean bran is the second most used ingredient as a source of protein in the production of feed for aquaculture. However, these ingredients compete with other feed segments, increasing cost or reducing market availability. Therefore, alternative sources of protein must be studied and developed to meet this demand. In this sense, insects present themselves as sources of high quality protein, in addition to fatty acids, vitamins and minerals. Although there is a problem with large-scale production to meet the demand of the feed market, the ease of breeding certain species of insects is capable of making this reality possible. Thus, insects can be a likely alternative protein source in fish feed, replacing conventional sources. This review aims to evaluate the inclusion of mealworm in the fish diet, in terms of performance and discuss the results obtained.
\end{abstract}

Keywords: Alternative protein fonts; Coleoptera; Fish meal; Insects; Production.

\section{Resumo}

A criação de organismos aquáticos está em constante crescimento e com isso surge a necessidade de suprir essa demanda com o aumento da produção de insumos como rações para a aquicultura. A nutrição de peixes é caracterizada principalmente pelo uso de farinha e óleo de peixe para a fabricação de rações para sua alimentação. $\mathrm{O}$ farelo de soja é o segundo ingrediente mais utilizado como fonte de proteína na produção de rações para aquicultura. No entanto, esses ingredientes competem com outros segmentos de rações, aumentando o custo ou reduzindo a disponibilidade no mercado. Portanto, fontes alternativas de proteína devem ser estudadas e desenvolvidas para atender a essa demanda. Nesse sentido, os insetos se apresentam como fontes de alta qualidade protéica, além de ácidos graxos, vitaminas e minerais. Embora exista um problema com a produção em larga escala para atender a demanda do mercado de rações, a facilidade de criação de certas espécies de insetos são capazes de tornar essa realidade possível. Assim, os insetos podem ser uma provável fonte proteica alternativa na alimentação de peixes, substituindo as fontes convencionais. Esta revisão tem como objetivo avaliar a inclusão da larva da farinha na dieta de peixes, sob os aspectos de desempenho e discutir os resultados obtidos.

Palavras-chave: Fonte proteica alternativa; Coleoptera; Farinha de peixe; Insetos; Produção. 


\begin{abstract}
Resumen
La creación de organismos acuáticos está en constante crecimiento y con ello surge la necesidad de satisfacer esta demanda con el aumento de la producción de insumos como piensos para la acuicultura. La nutrición de los peces se caracteriza principalmente por el uso de harina y aceite de pescado para la elaboración de raciones para su alimentación. El salvado de soja es el segundo ingrediente más utilizado como fuente de proteínas en la producción de piensos para la acuicultura. Sin embargo, estos ingredientes compiten con otros segmentos de piensos, aumentando los costos o reduciendo la disponibilidad del mercado. Por lo tanto, se deben estudiar y desarrollar fuentes alternativas de proteína para satisfacer esta demanda. En este sentido, los insectos se presentan como fuentes de proteínas de alta calidad, además de ácidos grasos, vitaminas y minerales. Aunque existe un problema con la producción a gran escala para satisfacer la demanda del mercado de piensos, la facilidad para criar ciertas especies de insectos es capaz de hacer posible esta realidad. Por lo tanto, los insectos pueden ser una fuente de proteína alternativa probable en la alimentación de los peces, en sustitución de las fuentes convencionales. Esta revisión tiene como objetivo evaluar la inclusión de larvas de harina en la dieta de los peces, en términos de rendimiento y discutir los resultados obtenidos.

Palabras clave: Fuente de proteína alternativa; Coleópteros; Harina de pescado; Insectos; Producción.
\end{abstract}

\title{
1. Introduction
}

The global production of aquatic organisms reached around 179 million tonnes in 2018, of which 82 million tonnes came from aquaculture production and these fish accounted for 54.3 million tonnes production. Of this amount (179 million tonnes), 156 million tonnes were used for human consumption, equivalent to an estimated annual supply of $20.5 \mathrm{~kg}$ per capita. The remainder of the production (22 million tonnes) was destined for non-food uses, mainly fishmeal and oil (FAO, 2020), necessary for industrial production of aquatic foods.

Increasing fish production will also require an improvement in the quality and quantity of the feed marketed. Compared to other non- ruminants animals, fish needed more protein, mainly from ingredients such as fishmeal and soybean meal, the most widely used sources today. According to Ferreira et al. (2013), the requirement of fish protein is prioritized in nutritional studies due to its high food cost, which represents more than $60 \%$ of food costs, since the price of feed is directly linked to protein content.

Currently, about $70 \%$ of fishmeal is used as aquaculture animals feed and this share increases to $75 \%$ for fish oil (OECD / FAO, 2019). However, the high global demand for these ingredients and competition with other sectors, such as pet feeding, has caused a reduction in natural fish stocks, leading to a shortage of supply and higher prices (Tacon et al., 2012 ; FAO, 2020).

Soybean meal, a product widely used in animal nutrition, is one of the most widely used sources of plant protein due to its high protein content and amino acid profile (Gatlin et al., 2007; Fontes et al., 2019). However, the presence of some antinutritional factors (tannins, saponins) and unfavorable factors (protease inhibitors, non-digestible oligosaccharides for fish, lectins) limits their inclusion in large amounts, as they can damage the intestinal mucosa of fish, affecting absorption of nutrients, growth and even intoxication (Hertrampf \& Piedad-Pascual, 2000; Heikkinen et al., 2006; Gatlin et al., 2007). Fluctuations in the value of the product and use by other animal species, especially swine and poultry, (Barone, 2017; United Soybean Board, 2019; Fraanje \& Garnett, 2020), make the product competitive by increasing the price of feed.

In this context, insects represent an innovative ingredient rich in high-quality proteins, as well as other beneficial nutrients such as fats, minerals and vitamins (Rumpold \& Schlüter, 2013; FAO, 2013). Moreover, the use of insects as a protein source for fish feeding does not compete with human food sources. Insects have key characteristics, such as short life cycles and the ability to take advantage of plant residues, converting them into high quality nutrients (IPIFF, 2018; Berggren, Jansson \& Low, 2019). The massive and large-scale production of these animals opens the possibility of reducing cost and achieving economic viability in the replacement of ingredients such as fishmeal and soybean meal (Khan et al., 2016), in addition to being considered an alternative in the search for sustainability environmental impact of the productive sector.

Tenebrio molitor, also known as mealworm, is one of the most studied insect species in the world, both in human and 
animal food. The main highlight of Tenebrio molitor is in the larval stage, which has a high protein content (47 to $60 \% \mathrm{CP}$ ), presenting itself as a potential alternative protein source in animal feed (De Marco et al., 2015; Bovera et al. 2016).

\section{Biology and rearing of Tenebrio molitor}

Tenebrio molitor (Linnaeus, 1758) is a beetle that belongs to the Coleoptera order, Tenebrionidae family, native to Europe and currently distributed worldwide. It feeds on grains, flours and their by-products, but of little relevance in grain production, since their populations are very small (Ramos-Elorduy et al., 2002). Larvae are easy to produce and have a valuable protein profile (Bednářová et al., 2013). For this reason, they are industrially produced for use in pets and zoological animals, as well as birds, reptiles, amphibians, small mammals and fish (Aguilar-Miranda et al., 2002; Hardouin \& Mahoux, 2003; Veldkamp et al., 2012). After reaching 8 to 10 weeks of cultivation, the larvae are sifted and separated from the substrate, placed without food at a temperature between $6^{\circ} \mathrm{C}$ and $15^{\circ} \mathrm{C}$ to eliminate the existing contents in the intestine (Conselho Superior de Saúde, 2014). Larvae can be used alive, cooled, frozen, dehydrated or in the form of flour (Ribeiro, 2019). The life cycle of beetle is summed up in Figure 1.

Figure 1. Life Cycle of Mealworm.

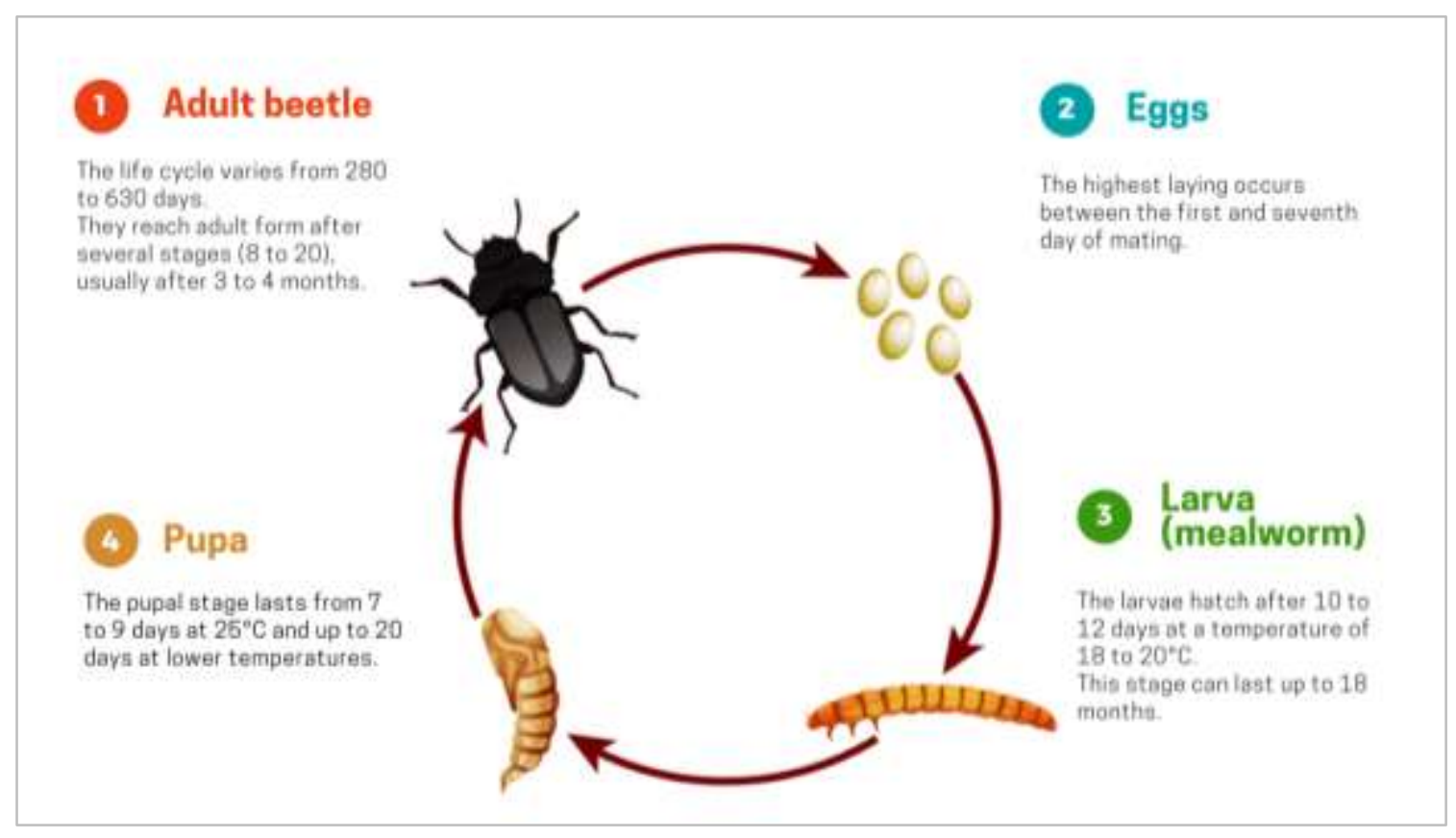

Source: Adapted by the authors from Freepik.

The standard diet for the insect T. molitor is based on wheat bran (Menezes et al., 2014). Other foods such as corn can be provided without affecting their development (Sánchez \& Burgos, 2014), although their performance is lower that of $T$. molitor fed with wheat bran (Souza \& Teles, 2011). The yellow mealworm is omnivorous and can feed on materials with less digestibility, such as feathers (Ramos-Elorduy et al., 2002; Finke, 2002). T. molitor can also take advantage of organic byproducts from brewing, baking, bioethanol production and potato processing into high quality food, rich in energy, protein and fat, which can be used in animal feed (van Broekhoven et al., 2015). In addition, they are able to metabolize the fungus zearalenone, in alpha-zearalenol, without accumulating it in their body, so that it does not affect animals that ingest products manufactured from their larvae (Hornung, 1991). Regarding the possible presence of pathogens, a previous treatment of larvae by short stage of heating or bleaching showed a significant reduction in total microbial load and enterobacteria count (Klunder et al., 2012; Megido et al., 2017). 
The composition of the mealworm is high in protein (47-60\%) and lipids (31-43\%) and it is profiles in amino acids and fatty acids and suitable for inclusion in animal feed (Makkar et al., 2014). Similar to soybean, the essential limiting amino acid in mealworm is methionine (Veldkamp \& Bosch, 2015). Belforti et al. (2015) reported low ash content (<5\% DM), low calcium and $\mathrm{Ca}: \mathrm{P}$ ratio $(133 \mathrm{ppm} / 3.345 \mathrm{ppm})$. Thus, it is necessary to supplement calcium in the diet of larvae to improve the quality of the ingredient (Vilella, 2018).

The large-scale production of T. molitor depends on several factors, such as the techniques used for multiplication, feed stock used, insect management at different stages of development, quality control and production costs. Other factors related to the insects physiology, such as adaptability to diet, reproductive potential, fecundity and fertility should also be taken into account (Parra, 2009; Junior et al., 2018). The environmental factors with the greatest impact on the production of $T$. molitor are temperature $\left(25\right.$ to $\left.27^{\circ} \mathrm{C}\right)$ and relative humidity $(30$ to $70 \%)$, in addition to food quality and absence of pathogens and stressors (Spang, 2013; Ribeiro, 2019). The whole and defatted T. molitor meal has a good value of essential amino acids (Figure 2). With the removal of fat, there is a higher concentration of amino acids.

Figure 2. Composition essencial amino acids (\% DM).

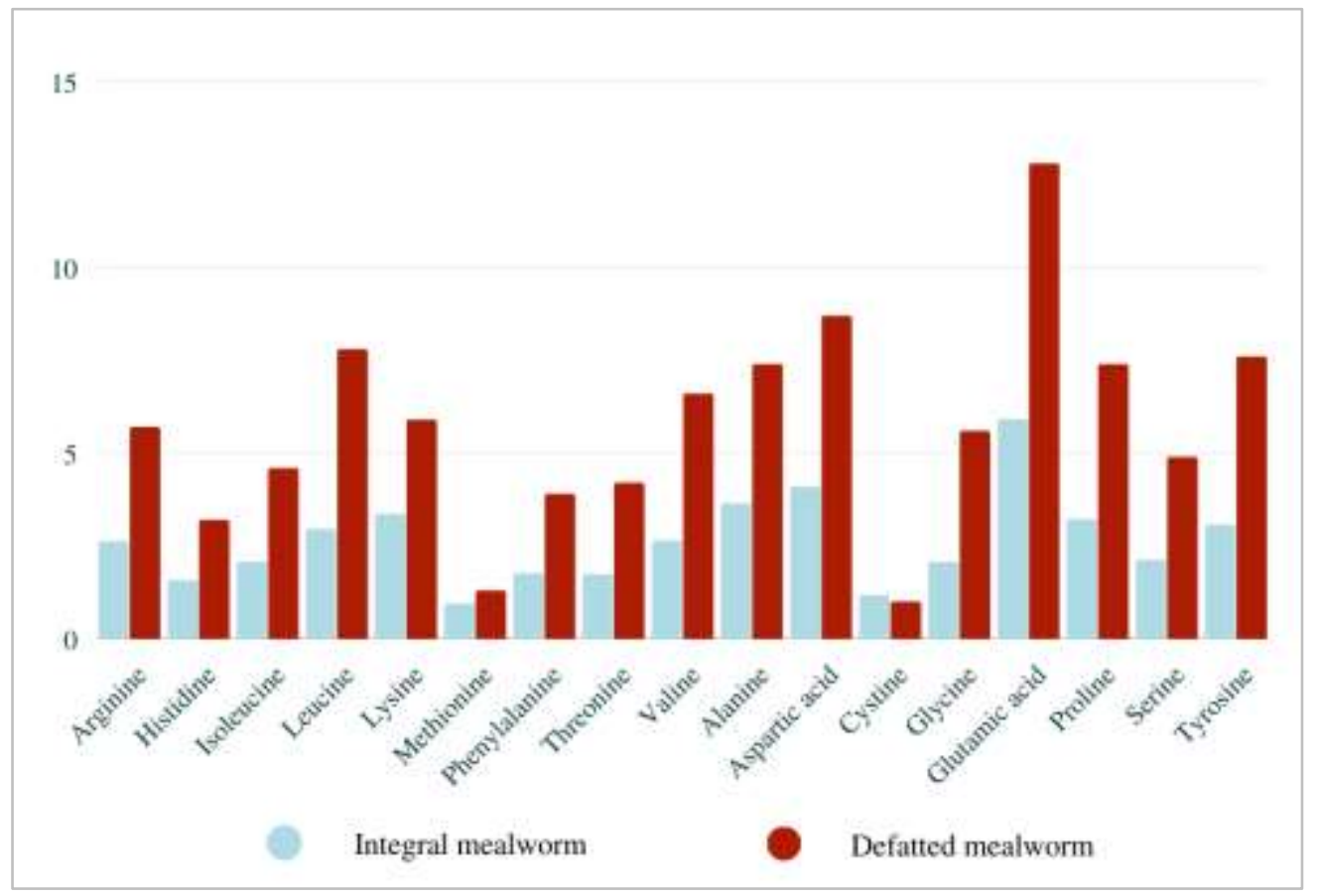

Source: Adapted by the authors from Iaconisi et al. (2017) and Ido et al. (2019).

\section{Use of mealworm in fish diets}

\subsection{Digestibility}

In recent years, the inclusion of insects as food has been widely explored, however, few studies have focused on the digestibility of nutrients and energy (Fontes et al., 2019). Insect species, inclusion level, life phase and fish species are related to changes in digestibility (Henry et al., 2015). Therefore, it should not be considered just one aspect to make recommendations on the inclusion of mealworm in fish diets.

The characterization and determination of bioavailable nutrients in food ingredients are crucial for the proper formulation of fish diets, to meet the requirements of nutritional species (Basto et al., 2020). The availability of nutrients in an ingredient is generally evaluated by determining the in vivo values of the apparent digestibility coefficient (ADC), which 
indicates the proportion of ingested nutrients that are not excreted in feces and can be used by the body (Glencross et al., 2007; Piccolo et al., 2014; Basto et al., 2020). Dry matter ADC provides a general indication of the digestibility of an ingredient, reflecting the digestible fraction of organic and inorganic matter, which are highly variable according to their insoluble carbohydrates and mineral composition, respectively (NRC, 2011; Basto et al., 2020).

Generally, the effect of insect intake on the digestibility of food nutrients is affected by chitin, but studies show that the effect depends on the level of inclusion (Piccolo et al., 2014). Chitin, linear homopolymer of the n-acetylglucosamine units bound $\beta(1-4)$, is the main component of insect cuticles, where it is bound to protein, which reduces the apparent and true digestibility of nitrogen. For fish to use chitin, they must be able to digest and use it, otherwise chitin will become an energy sink, reducing potential energy availability. Undigested chitin can also affect nutrient use, being known to absorb lipids and bile into the gastrointestinal tract, thus decreasing lipid digestion and absorption (Tharanathan \& Kittur, 2003).

The hypothesis that non-ruminants animals, including fish, cannot digest chitin due to the presence or lack of chitinolytic enzymes, has already been ruled out. Studies have proven the presence and activity of chitinolytic enzymes in several fish organs, such as gastric mucosa, intestinal mucosa, pilorich cecos and pancreas (Jeuniaux, 1993; Krogdahl et al., 2005; Ikeda et al., 2012; Ikeda et al., 2014). Some results on digestibility are summarized in Table 1.

Genes of the chitinase enzyme were sequenced in carnivorous marine teleosteos, showing that some fish are capable of producing chitinase and, therefore, degrading chitin (Kurokawa et al., 2004; Piccolo et al., 2014). The location of enzymes varies between studies and species, with some finding greater activity in the stomach, while others showed higher activity in the intestine. There are also some data indicate that fish that eat rich prey in chitin have higher chitinase activity than other fish (Gutowska et al., 2004) and that diets rich in chitin will increase enzymatic activity (Danulat, 1987).

In the study by Gasco et al. (2016), the inclusion of $25 \%$ of mealworm meal (MWM) with exogenous enzymes reduced the digestibility of carbohydrates and proteins. Supplementation with digestive enzymes may have negatively affected the viability of the intestinal microbiota, which helps in the digestive activity of fish (Ringø et al., 2015). Proteases and carbohydrases (mainly $\beta$-glucanases), present in diets may have harmed proteins and carbohydrates present on the surface of gram-negative bacteria (Beveridge, 1999) or the surface proteins present in the gram-positive bacterial membrane (Navarre \& Schneewind, 1999; Desvaux et al., 2006), thus decreasing digestive activity towards the insect's chitin (Gasco et al., 2016).

Fontes et al. (2019) in study with Nile tilapia fingerlings, observed that diets with tenebrian meals (T. molitor and $Z$. morio) had dry matter ADC close to the values reported by Köprücü and Özdemir (2005) for fishmeal and soybean meal. Sánchez-Muros et al. (2015) in their study indicated that MWM has a composition comparable to soybean meal and that partial replacement of fish meal or total replacement of soybean meal by MWM does not affect food intake and protein digestibility in vitro.

For European sea bass (Dicentrarchus labrax), the digestibility of insects meal larvae (whole and defatted) was evaluated: Hermitia illucens (HW and HID), Tenebrio molitor (TMW and TMD) and grasshopper meal (GM) (Basto et al. 2020). According to the authors, the defaturing process provides an increase in protein content, as already reported by Teh et al. (2013) and Choi et al. (2017). Due to the high digestibility of protein (> 89\%) and the high amount of digestible essential amino acids, it is suggested that T. molitor meal are the most promising protein sources for European sea bass, with the potential to replace fish meal (Basto et al., 2020).

Therefore, the defatter method is important to ensure greater storage and processing. This is because the larvae of $T$. molitor have a high fat composition (25-35\%) and fatty acids (10-30\%), making the ingredient susceptible to lipid oxidation during drying and storage (Ghosh et al., 2017; Lenaerts et al., 2018).

According to Maehre et al. (2018), the protein content of an ingredient must be calculated directly from the sum of its individual amino acids (true protein). Due to the high costs associated with the quantification of total amino acids, this method 
often ends up being inaccessible. Thus, the protein content of foods based on nitrogen determination with subsequent conversion using a Nitrogen Kp (equilibrium constant) for protein of 6.25 (crude protein). Considering that insects contain non-protein nitrogen, some authors suggest using lower Kp values to avoid overestimating protein content. In this context, Janssen et al. (2017) calculated a specific Kp of 4.76 for whole larvae of T. molitor and H. illucens, but suggested a factor of 5.60 after protein extraction (Basto et al. 2020). Thus, all of these factors together are important for the correct determination of the nutritional value of this new and potential ingredient, as well a additional studies on it is use by marine and freshwater fish.

Table 1. Digestibility of mealworm meal (MWM) in different fish species.

\begin{tabular}{|c|c|c|c|c|}
\hline Species & $\begin{array}{c}\text { MWM inclusion } \\
\text { level }\end{array}$ & Evaluated parameter & $\begin{array}{l}\text { MWM inclusion } \\
\text { response }\end{array}$ & Reference \\
\hline $\begin{array}{c}\text { Dourada } \\
\text { Sparus aurata }\end{array}$ & 30 and $60 \%$ & $\begin{array}{l}\text { ADC of the dry matter, crude protein and ether } \\
\text { extract. } \\
\text { Inclusion levels ( } 60 \% \text { of MWM), reduces the } \\
\text { digestibility of nutrients, but does not cause } \\
\text { negative effects on growth compared to the } \\
\text { control group. }\end{array}$ & $\begin{array}{l}(\leftrightarrow) \\
(\uparrow)\end{array}$ & $\begin{array}{l}\text { Piccolo et } \\
\text { al. (2014) }\end{array}$ \\
\hline $\begin{array}{l}\text { Rainbow trout } \\
\text { (Oncorhynchus } \\
\text { mykiss) }\end{array}$ & 25 and $50 \%$ & $\begin{array}{l}\text { ADC of the dry matter, organic matterand ether } \\
\text { extract. } \\
\text { ADC of the crude protein. }\end{array}$ & $\begin{array}{l}(\leftrightarrow) \\
(\downarrow)\end{array}$ & $\begin{array}{l}\text { Belforti et } \\
\text { al. (2015) }\end{array}$ \\
\hline $\begin{array}{l}\text { Juvenile European } \\
\text { sea bass } \\
\text { (Dicentrarchus } \\
\text { labrax L.) }\end{array}$ & $25 \%$ & $\begin{array}{l}\text { ADC of dry matter and crude protein. } \\
\text { ADC of lipids and carbohydrates. } \\
\text { ADC of protein and carbohydrate when } \\
\text { exogenous proteases and exogenous } \\
\text { carbohydrateases were added to the diet. }\end{array}$ & $\begin{array}{l}(\leftrightarrow) \\
(\uparrow) \\
(\downarrow)\end{array}$ & $\begin{array}{l}\text { Gasco et al. } \\
\quad(2016)\end{array}$ \\
\hline $\begin{array}{l}\text { Fingerlings } \\
\text { Nile tilapia } \\
\text { (Oreochromis } \\
\text { niloticus) }\end{array}$ & $20 \%$ & $\begin{array}{l}\text { ADC of the dry matter, protein, corrected } \\
\text { protein and chitin in relation to the other tested } \\
\text { insect meal (cockroaches Nauphoeta cinerea } \\
\text { and Gromphadorhina portentosa, tenebrio } \\
\text { Zophobas morio and grilo Gryllus assimilis). }\end{array}$ & $(\uparrow)$ & $\begin{array}{l}\text { Fontes et } \\
\text { al. (2019) }\end{array}$ \\
\hline $\begin{array}{l}\text { Juvenile } \\
\text { Rainbow trout } \\
\text { (Oncorhynchus } \\
\text { mykiss) }\end{array}$ & $5,7.5,15$ and $25 \%$ & Dry matter, protein, fat, phosphorus and energy. & $(\leftrightarrow)$ & $\begin{array}{l}\text { Rema et al. } \\
\text { (2019) }\end{array}$ \\
\hline $\begin{array}{l}\text { Juvenile European } \\
\text { sea bass } \\
\text { (Dicentrarchus } \\
\text { labrax) }\end{array}$ & $20 \%$ & $\begin{array}{l}\text { ADC of protein for reference diet }(92,6 \%) \text {, } \\
\text { MWM }(91,8 \%) \text { and MWMd }(92,6 \%), \\
\text { comparad to other diets. } \\
\text { ADC of fat in the reference diet }(98,2 \%) \text { and } \\
\text { MWMd }(97,7 \%) \text { in relation to other treatments. } \\
\text { ADC of the gross energy in the reference diet } \\
(86,5 \%) \text { and MWMd }(86,1 \%) \text { significant and } \\
\text { higher compared to other diets. } \\
\text { ADC of phosphorus to MWM }(63,6 \%) \text { and } \\
\text { MWMd }(63,9 \%) \text { compared to the reference } \\
\text { diet. }\end{array}$ & $(\uparrow)$ & $\begin{array}{l}\text { Basto, } \\
\text { Matos \& } \\
\text { Valente } \\
(2020)\end{array}$ \\
\hline $\begin{array}{l}\text { Rainbow trout } \\
\text { (Oncorhynchus } \\
\text { mykiss) }\end{array}$ & 5,10 and $20 \%$ & $\begin{array}{l}\text { ADC of dry matter, ether extract and gross } \\
\text { energy. } \\
\text { ADC of crude protein with the inclusion of } \\
\text { MWMd in the diet, in relation to the control } \\
\text { diet. }\end{array}$ & $(\leftrightarrow)$ & $\begin{array}{l}\text { Chemello } \\
\text { et al. } \\
(2020)\end{array}$ \\
\hline
\end{tabular}

$(\uparrow)$ increase; $(\downarrow)$ decrease; $(\leftrightarrow)$ no change. Apparent digestibility coefficient (ADC); yellow mealworm meal (MWM); yellow mealworm meal defatted (MWMd). Source: Authors. 


\subsection{Growth parameters}

Growth analysis is extremely important to know if fish is efficiently transforming nutrients ingested into the diet. Table 2 presents some consistent studies and the results obtained with some fish species fed mealworm meal (MWM).

The decrease in voluntary intake by rainbow trout (Oncorhynchus mykiss) fed diets containing MWM (-3.6 and -6.4\% for 25 and $50 \%$, respectively) causes improvement in feed conversion, protein efficiency rate and specific growth rate. The main factor related to reduction of intake is the high amount of fat and the type of fatty acids that compose it. For trout it is possible to include MWM in the diet without compromising performance (Belforti et al., 2015).

Piccolo et al. (2017) suggest that the improvement in the performance of sea bream (Sparus aurata) fed with $25 \%$ inclusion of MWM in the diet can be attributed to the prebiotic activity of chitin at lower concentrations (Sakai et al., 1992; Esteban et al., 2001; Piccolo et al., 2017), which increased the production of butyrate in the cecum (Khempaka et al., 2011; Bovera et al., 2016; Loponte et al., 2016) having a positive effect on bowel development. (Bovera et al., 2016). Butyric acid is considered the main source of energy for enterocytes (Bovera et al., 2010), it is also necessary for the proper development of the gut-associated lymphoid tissue (Mroz, 2005). In the statement, the intestinal length of fish fed the a diet of $25 \%$ MWM was higher than that of fish fed the control diet (Piccolo et al., 2017).

Although the substitution of fishmeal by MWM has been tested in many studies, high levels of insects inclusion in fish diets have resulted in reduced growth in many cases, particularly in carnivorous marine fish species (Sánchez-Muros et al., 2014), as observed by Gasco et al. (2016) in juveniles of European sea bass (Dicentrarchus labrax. L). According to Skalli \& Robin (2004), the minimum diet requirement for long-chain fatty acids ( $\omega$-3) for the adequate growth of juveniles of $D$. labrax is $0.7 \%$ based on dry matter (DM), lower values decrease the performance of fish growth without negative effects on feed efficiency or protein efficiency ratio. In this context, Gasco et al. (2016) found that the minimum requirements for polyunsaturated fatty acids (PUFA $\omega$-3) were not met in the inclusion of $50 \%$ MWM in the diet, which may explain the significant decrease in weight gain and specific growth rate of fish.

The results of the somatic hepato index (SHI) differ between fish species (rainbow trout and European sea bass). SHI is generally used to investigate the effects of food on the liver as it is the essential organ for metabolism (Dernekbaşi, 2012). The standard values of SHI range from 1 to $2 \%$, a percentage higher than what shows that the diet caused some problem in fish, especially in the metabolism of carbohydrates and fats, and there may be oxidized foods in the diet, extra carbohydrates or vitamin deficiency (Munshi \& Dutta, 1996). Thus, the trend of decrease in SHI with increased level of inclusion of MWM in the diet was similar to that observed in other studies, where fishmeal was completely or partially replaced by insect meal or plant proteins (Sealey et al., 2011).

Whole mealworm veres have excess raw lipids (30 to $35 \%$ in DM), so an extraction process is requered to obtain an adequate food composition (Henry et al., 2015). Ido et al. (2019) observed that the inclusion of MWM without the lipid fraction promoted increase growth and food intake of Red seabream (Pargus major) compared to the MWM diet with the lipid fraction. Rema et al. (2019) found that deffat mealworm (MWMd) can replace up to $100 \%$ of fishmeal in the juvenile rainbow trout diet with positive results in performance indexes and nutrient retention.

According to Finke (2002), the energy requirement of fish is lower than that of mammals. Cold-water carnivorous fish, such as salmonids, can adapt to dietary lipid levels of up to 35\%, but higher levels can lead to reduced fish growth or lipid deposition (New \& Wijkstroem, 2002).

Herbivorous and omnivorous fish of warm water tolerate maximum levels of dietary lipids between 10 and $20 \%$, allowing for optimal growth rates without producing an excessively fatty carcass (Hasan, 2001; Sales \& Janssens, 2003). High levels of dietary lipids (above 20\%) can impair the immune status of some species of marine omnivorous fish (Henry \& Fountoulaki, 2014). In this context, the removal of the fat fraction of T. molitor larvae allows the ingredient to have a greater 
bioavailability in the diet, that is, a higher protein concentration, which can consequently promote an increase in fish growth. Therefore, the diet provided to insects during the growing period is the main responsible for variations in composition of lipid and fatty acid of the larvae (Barroso et al., 2014).

Hua (2021), in a recent meta-analysis, indicates that the effects of insect meal levels on fish growth were influenced by the nutritional balance of the diet. It was observed that when diets were unbalanced, the increasing in insect meal levels had a negative linear effect on the growth rate. However, when the insect inclusion diets were balanced there was no adverse effect on fish growth to a certain level, and a negative effect was shown only when insect inclusion levels reached a certain threshold. The differences in the results emphasize the need to ensure nutritional adequacy and parity of experimental diets containing insect meal compared to control diets containing fishmeal.

Knowing that mealworm has low ash values of 3 to 6\% (Barroso et al., 2014; Makkar et al., 2014; Sánchez-Muros et al., 2014; Marono et al., 2015) and low methionine (Khosravi et al., 2018), if the experimental diet is formulated with insect meals to replace fish meal without balancing the composition of nutrition between diets, the negative effects of these meals on fish growth may be due to nutrient deficiency and therefore, mask the evaluation or comparison of the nutritional values of the insect meal (Hua 2021).

Table 2. Growth parameters in fish fed with the inclusion of mealworm meal (MWM) in the diet.

\begin{tabular}{|c|c|c|c|c|}
\hline Species & MWM inclusion level & Evaluated parameter & $\begin{array}{l}\text { MWM inclusion } \\
\text { response }\end{array}$ & Reference \\
\hline $\begin{array}{c}\text { Rainbow trout } \\
\text { (Oncorhynchus } \\
\text { mykiss) }\end{array}$ & 25 and $50 \%$ & $\begin{array}{l}\text { Final body weight and weight gain. Specific } \\
\text { growth rate and protein efficiency rate with } \\
\text { increasing inclusion, compared to the } \\
\text { control group. } \\
\text { Feed consumption by fish in the control } \\
\text { group compared to groups with MWM } \\
\text { inclusion ( } 1.41 \text { vs } 1.35 \text { and } 1.31 \% \text { for } 0,25 \\
\text { and } 50 \% \text {, respectively). } \\
\text { Feed conversion rate with increasing } \\
\text { inclusion levels compared to the control } \\
\text { group. } \\
\text { Survival rate with increasing inclusion level } \\
\text { ( } 96.7 \text { and } 97.5 \% \text { to } 25 \text { and } 50 \% \text {, } \\
\text { respectively) compared to the control group } \\
\text { (86.7\%). } \\
\text { HSI with increasing inclusion level. }\end{array}$ & $\begin{array}{l}(\downarrow) \\
(\uparrow) \\
(\downarrow)\end{array}$ & $\begin{array}{l}\text { Belforti et al. } \\
\text { (2015) }\end{array}$ \\
\hline
\end{tabular}




\begin{tabular}{|c|c|c|c|c|}
\hline $\begin{array}{c}\text { Nile tilapia } \\
\text { (Oreochromis } \\
\text { niloticus) }\end{array}$ & 21 and $43 \%$ & $\begin{array}{l}\text { Final body weight, daily growth coefficient, } \\
\text { feed conversion efficiency and protein } \\
\text { efficiency rate with increasing MWM } \\
\text { inclusion in the diet. } \\
\text { Feed consumption, but had an increase } \\
\text { compared to the control diet. } \\
\text { Condition factor. }\end{array}$ & $\begin{array}{l}(\downarrow) \\
(\leftrightarrow) \\
(\leftrightarrow)\end{array}$ & $\begin{array}{c}\text { Sánches-Muros et } \\
\text { al. (2016) }\end{array}$ \\
\hline
\end{tabular}

\begin{tabular}{|c|c|c|c|c|}
\hline $\begin{array}{c}\text { Juvenile European sea } \\
\text { bass (Dicentrarchus } \\
\text { labrax L.) }\end{array}$ & 25 and $50 \%$ & $\begin{array}{l}\text { Final body weight, weight gain, DM intake, } \\
\text { specific growth rate and feeding rate with } \\
\text { increasing inclusion of MWM in the diet. } \\
\text { HSI of fish fed with MWM at } 25 \% \text { in the } \\
\text { diet. } \\
\text { Fish mortality. } \\
\text { Feed conversion ratio and protein efficiency } \\
\text { ratio. }\end{array}$ & $\begin{array}{l}(\downarrow) \\
(\uparrow) \\
(\leftrightarrow) \\
(\leftrightarrow)\end{array}$ & Gasco et al. (2016) \\
\hline $\begin{array}{l}\text { Gilthead sea bream } \\
\text { (Sparus aurata) }\end{array}$ & 30 and $60 \%$ & $\begin{array}{l}\text { Condition factor in relation to fish in the } \\
\text { control diet. } \\
\text { Final body weight, weight gain, feed } \\
\text { conversion ratio and protein efficiency ratio } \\
\text { at the inclusion of } 25 \% \text {. } \\
\text { Intestinal length at the inclusion of } 25 \% \\
\text { compared to the control diet. } \\
\text { HSI of fish fed the } 50 \% \text { inclusion diet, } \\
\text { compared to the control group. }\end{array}$ & $\begin{array}{l}(\uparrow) \\
(\uparrow) \\
(\uparrow) \\
(\uparrow)\end{array}$ & $\begin{array}{l}\text { Piccolo et al. } \\
\text { (2017) }\end{array}$ \\
\hline $\begin{array}{l}\text { Yellow catfish } \\
\text { (Pelteobagrus } \\
\text { fulvidraco })\end{array}$ & 9,18 and $27 \%$ & $\begin{array}{l}\text { Feed rate, specific growth rate and feed } \\
\text { conversion efficiency. } \\
\text { Feed conversion efficiency at } 9 \% \text { of } \\
\text { inclusion in relation to the other treatments, } \\
\text { but it was not significant. }\end{array}$ & $\begin{array}{l}(\leftrightarrow) \\
(\uparrow)\end{array}$ & Su et al. (2017) \\
\hline $\begin{array}{c}\text { Juvenile Pearl Gentian } \\
\text { grouper }(E . \\
\text { lanceolatus x } E \text {. } \\
\text { fuscoguttatus })\end{array}$ & $\begin{array}{c}2.5,5,7.5,10 \\
\text { and } 12.5 \%\end{array}$ & $\begin{array}{l}\text { Final body weight and weight gain rate in } \\
\text { relation to the other diets. } \\
\text { Feed conversion rate at } 10 \text { and } 12.5 \% \text { of } \\
\text { MWM inclusion in relation to the other } \\
\text { diets. } \\
\text { Specific growth rate and temperature } \\
\text { growth coefficient. }\end{array}$ & $\begin{array}{l}(\uparrow) \\
(\uparrow) \\
(\leftrightarrow)\end{array}$ & Song et al. (2018) \\
\hline
\end{tabular}

\begin{tabular}{|c|c|c|c|c|}
\hline $\begin{array}{l}\text { Juvenis de Mandarin } \\
\text { fish } \\
\text { (Siniperca scherzeri) }\end{array}$ & 10,20 and $30 \%$ & $\begin{array}{l}\text { Weight gain, specific growth rate, protein } \\
\text { efficiency rate and protein retention with } \\
\text { increasing MWM level in the diet up to } \\
20 \% \text {. } \\
\text { Weight gain, specific growth rate, protein } \\
\text { efficiency rate and protein retention with } \\
\text { increasing MWM levels in the diet. } \\
\text { Survival with increasing levels of inclusion. } \\
\text { Feed conversion rate up to } 20 \% \text { inclusion. } \\
\text { Condition fator and HSI. }\end{array}$ & $\begin{array}{c}(\downarrow) \\
\\
(\uparrow) \\
(\downarrow) \\
(\leftrightarrow)\end{array}$ & $\begin{array}{c}\text { Sankian et al. } \\
\text { (2018) }\end{array}$ \\
\hline $\begin{array}{l}\text { Juvenis de Rockfish } \\
\text { (Sebastes schlegeli) }\end{array}$ & $8,16,24$ and $32 \%$ & $\begin{array}{l}\text { Weight gain, specific growth rate and } \\
\text { protein retention up to the inclusion of } 16 \% \\
\text { MWM in the diet. } \\
\text { Daily feed intake, protein efficiency ratio } \\
\text { and feed conversion ratio. } \\
\text { HSI with the inclusion of MWM in the diet } \\
\text { compared to fish fed the control diet. }\end{array}$ & $\begin{array}{l}(\leftrightarrow) \\
(\downarrow)\end{array}$ & $\begin{array}{c}\text { Khosravi et al. } \\
\text { (2018) }\end{array}$ \\
\hline
\end{tabular}




\begin{tabular}{|c|c|c|c|c|}
\hline $\begin{array}{l}\text { Red Seabream } \\
\text { (Pargus major) }\end{array}$ & 25,40 and $65 \%$ & $\begin{array}{l}\text { Growth, weight gain rate and specific } \\
\text { growth rate of fish with complete } \\
\text { replacement of fishmeal by inclusion of } \\
\text { MWMd in the diet. } \\
\text { Feed conversion rate. } \\
\text { The survival rate, however, was higher in } \\
\text { fish fed MWMd ( } 96.9 ; 100 \text { and } 100 \% \text {, } \\
\text { respectively) compared to fish in the control } \\
\text { group ( } 90.6 \%) \text {. }\end{array}$ & $\begin{array}{c}(\uparrow) \\
(\leftrightarrow) \\
(\leftrightarrow)\end{array}$ & Ido et al. (2019) \\
\hline $\begin{array}{l}\text { Juvenile Rainbow } \\
\text { trout } \\
\text { (Oncorhynchus } \\
\text { mykiss) }\end{array}$ & $5,7.5,15$ and $25 \%$ & $\begin{array}{l}\text { Final body weight with increasing inclusion } \\
\text { of MWMd in the diet compared to the } \\
\text { control diet. } \\
\text { Specific growth rate of the control group in } \\
\text { relation to fish fed the diet with MWMd. } \\
\text { Conversion rate with increasing inclusion of } \\
\text { MWMd in the diet. } \\
\text { Protein efficiency rate in diets with MWMd } \\
\text { compared to the control diet. }\end{array}$ & $\begin{array}{l}(\downarrow) \\
(\downarrow) \\
(\uparrow)\end{array}$ & Rema et al. (2019) \\
\hline $\begin{array}{l}\text { Juvenile Rainbow } \\
\text { trout } \\
\text { (Oreochromis } \\
\text { niloticus) }\end{array}$ & $5,10,15$ and $20 \%$ & $\begin{array}{l}\text { Final weight, weight gain, feed intake and } \\
\text { specific growth rate with increasing MWM } \\
\text { inclusion compared to the control diet. } \\
\text { Feed conversion rate, survival and } \\
\text { productivity with increasing inclusion of } \\
\text { MWM in the diet. } \\
\text { HSI with increasing inclusion of MWM in } \\
\text { the diet. }\end{array}$ & $\begin{array}{l}(\downarrow) \\
(\uparrow)\end{array}$ & Tubin et al. (2020) \\
\hline $\begin{array}{l}\text { Rainbow trout } \\
\text { (Oncorhynchus } \\
\text { mykiss) }\end{array}$ & 5,10 and $20 \%$ & $\begin{array}{l}\text { Mortality and growth performance. } \\
\text { Condition factor and somatic indices. } \\
\text { HSI in the diet including } 20 \% \text { MWMd (total } \\
\text { replacement of fishmeal). }\end{array}$ & $\begin{array}{l}(\leftrightarrow) \\
(\leftrightarrow) \\
(\uparrow)\end{array}$ & $\begin{array}{l}\text { Chemello et al. } \\
\text { (2020) }\end{array}$ \\
\hline
\end{tabular}

$(\uparrow)$ increase; $(\downarrow)$ decrease; $(\leftrightarrow)$ no change. Mealworm meal (MWM); Hepato somatic index (HSI). Source: Authors.

\subsection{Body composition}

The fish's diets have significant influence on the parameters and quality characteristics of fish and their fillets, suchas color, texture, nutritional and functional properties, shelf life and lipid content (Lie, 2001; De Francesco et al., 2007; GarcíaRomero et al., 2014; Tibaldi et al., 2015).

Essential fatty acids are composed mainly of unsaturated fatty acids (UFA), that is, they present at least one unsaturation in the molecule. Polyunsaturated fatty acids (PUFA) have two or more unsaturation acids and are classified as linoleic acid (AL, C18: 2n6), alpha-lyric acid (ALA, C18: 3n3), eicosapentaenoic acid (EPA, C20: 5n3), docosahexaenoic acid (DHA, C22: 6n3) and docosapentaenoic acid (DPA, C22: 5n3), which are of scientific importance, as they are considered essential because they are not synthesized by the human body (Kus \& Mancini-Filho, 2010).

The fatty acids of the n-3 and n-6 series are precursors of eicosanoid acids and are mainly provided by the diet. Linoleic acid originates arachidonic acid, precursor of eicosanoids, thromboxanes and prostacyclin (I2), respectively promoter and inhibitor of platelet aggregation (Ramos Filho et al., 2008).

ALA, precursor of EPA and DHA, responsible for the development and functioning of the nervous system, photoreception and reproductive system (Celik et al., 2005) are indicated to reduce the risk of coronary heart disease, moderate hypertension, incidence of diabetes and prevention of certain cardiac arrhythmias and sudden death (Menezes et al., 2009). Fish are rich sources of polyunsaturated fatty acids, especially those of the n-3 series, such as EPA. The type and content of fatty acids present in fish are influenced by genetic characteristics, habitat, quality and quantity of available food (phytoplankton and zooplankton) (Stansby et al., 1973). 
Thus, the dietary fatty acid profile significantly affects the fatty acid profile in fish tissue. Therefore, it is always important to evaluate the body composition of fish fed new sources of ingredients. Table 3 shows some of the results found for the inclusion of MWM in the fish diet.

In the study conducted by Iaconisi et al. (2017), the fatty acid profile of the lipid fraction of the black dot bream muscle fillet (Pagellus bogaraveo) was changed from fishmeal treatments. Thus, the incidence of AL increased progressively with the level of inclusion of MWM in the diet, and the opposite occurred with APA and DHA, which gradually decreased in the muscle of fish fed increasing levels of MWM. Similarly, Belforti et al. (2015) observed that these two fatty acids were strongly decreased in rainbow trout (Oncorhynchus mykiss), fed with feed at increasing levels of replacement of fishmeal by MWM.

Although they are rich in AL, saturated fatty acids (SFA) and monounsaturated fatty acids (MUFAs), the absence of polyunsaturated fatty acids from the $\mathrm{n}-3$ series, such as EPA and DHA is the main disadvantage of the use of insects as an alternative ingredient for fish feeding (Sánchez-Muros et al., 2014). Therefore, it is possible to see that the presence of insects in the diet is not only important as a source of protein, but also as a source of lipids, whose quantity and quality are directly influenced by the substrate that insect larvae consume (St-Hilaire et al., 2007; Kroeckel et al., 2012).

According to Belforti et al. (2015), the inclusion of MWM in the diets of rainbow trout significantly decreased the relative amount of fat, besides causing changes in the lipid profile of the dorsal muscle of fish. Thus, the authors suggest the application of a food strategy at the end of the growing season, that is, a period of hunger followed by a short period of diet rich in PUFA $\omega-3$, in an attempt to balance the negative effects of diets deficient in PUFA $\omega-3$ and overcome the worsening of fatty acid profile of fish fillets, which has been reported in previous studies (Zoccarato et al., 1994; Gause \& Trushenski, 2013). Another alternative would be to increase the concentration of PUFA $\omega-3$ in insect feeding through it is reproduction substrate (St-Hilaire et al., 2007). 
Table 3. Body composition of fish fed with inclusion of mealworm meal (MWM) in the diet.

\begin{tabular}{|c|c|c|c|c|c|}
\hline Species & $\begin{array}{c}\text { MWM } \\
\text { inclusion level }\end{array}$ & Body portion & Evaluated parameter & $\begin{array}{l}\text { MWM inclusion } \\
\text { response }\end{array}$ & Reference \\
\hline $\begin{array}{l}\text { Juvenile European } \\
\text { sea bass } \\
\text { (Dicentrarchus } \\
\text { labrax L.) }\end{array}$ & 25 and $50 \%$ & Whole body & $\begin{array}{l}\text { Centesimal composition. } \\
\text { Oleic acid and linoleic acid content. } \\
\text { EPA, DPA and DHA. } \\
\text { n3/n6 fatty acid ratio. }\end{array}$ & $\begin{array}{l}(\leftrightarrow) \\
(\uparrow) \\
(\downarrow) \\
(\downarrow)\end{array}$ & $\begin{array}{l}\text { Gasco et al. } \\
\text { (2016) }\end{array}$ \\
\hline $\begin{array}{c}\text { Rainbow trout } \\
\text { (Oncorhynchus } \\
\text { mykiss) }\end{array}$ & 25 and $50 \%$ & Dorsal muscle & $\begin{array}{l}\text { Crude protein content. } \\
\text { Dry matter and ethereal extract. } \\
\text { Total PUFA concentration with } \\
\text { increasing inclusion level. } \\
\text { Total concentration of n3 with } \\
\text { increasing inclusion level. } \\
\text { Total concentration of n6 with } \\
\text { increasing inclusion level. } \\
\text { Ratio of n3/n6 fatty acids with } \\
\text { increasing inclusion level, which } \\
\text { ranged from } 2.32 \% \text { (control) to } 0.41 \% \\
\text { (50\%). } \\
\text { EPA (C20:5n3), DPA ( } 22: 5 \mathrm{n} 3 \text { ) and } \\
\text { DHA ( } 22: 6 \mathrm{n} 3 \text { ) with increasing levels of } \\
\text { MWM inclusion. } \\
\text { ALA in the dorsal muscle of fish fed } \\
\text { with MWM inclusion in the diet (-26.5 } \\
\text { and -51.0\% for } 25 \text { and } 50 \% \text {, } \\
\text { respectively). } \\
\text { IA with increasing levels of inclusion of } \\
\text { MWM, due to the lower percentage of } \\
\text { PUFA } \omega-3 . \text { IT with the progressive } \\
\text { increase of MWM in partial } \\
\text { replacement of fishmeal. }\end{array}$ & $\begin{array}{l}(\uparrow) \\
(\downarrow) \\
(\uparrow) \\
(\downarrow) \\
(\uparrow) \\
(\downarrow)\end{array}$ & $\begin{array}{l}\text { Belforti et al. } \\
\quad(2015)\end{array}$ \\
\hline $\begin{array}{l}\text { Juvenile European } \\
\text { sea bass } \\
\text { (Dicentrarchus } \\
\text { labrax L.) }\end{array}$ & 25 and $50 \%$ & Whole body & $\begin{array}{l}\text { Dry matter, crude protein, ether extract } \\
\text { and mineral matter. } \\
\text { Concentration of oleic acid and linoleic } \\
\text { acid with increasing inclusion. } \\
\text { EPA, DPA and DHA with increasing } \\
\text { inclusion. } \\
\text { n3/n6 fatty acids ratio with increasing } \\
\text { inclusion. }\end{array}$ & $\begin{array}{l}(\leftrightarrow) \\
(\uparrow) \\
(\downarrow) \\
(\downarrow)\end{array}$ & $\begin{array}{l}\text { Gasco et al. } \\
\text { (2016) }\end{array}$ \\
\hline $\begin{array}{l}\text { Nile tilapia } \\
\text { (Oreochromis } \\
\text { niloticus) }\end{array}$ & 21 and $43 \%$ & Muscle & $\begin{array}{l}\text { Composition of macronutrients. } \\
\text { Arginine and histidine with increasing } \\
\text { inclusion level. } \\
\text { Oleic acid and linoleic acid. } \\
\text { EPA, DPA, DHA, eicosaenoic acid } \\
(20: 1 \text { n9). } \\
\text { With increasing inclusion. } \\
\text { n3/n6 fatty acids ratio with increasing } \\
\text { inclusion. }\end{array}$ & $\begin{array}{l}(\uparrow) \\
(\downarrow) \\
(\downarrow)\end{array}$ & $\begin{array}{l}\text { Sánchez- } \\
\text { Muros et al. } \\
\text { (2015) }\end{array}$ \\
\hline
\end{tabular}




\begin{tabular}{|c|c|c|c|c|c|}
\hline $\begin{array}{l}\text { Blackspot sea bream } \\
\text { (Pagellus bogaraveo) }\end{array}$ & 25 and $50 \%$ & Muscle & $\begin{array}{l}\text { Moisture, crude protein, ether extract, } \\
\text { total lipids and mineral matter. } \\
\text { PUFA n- } 6 \text { with increasing inclusion } \\
\text { level. } \\
\text { PUFA n-3 with increasing inclusion } \\
\text { level. } \\
\text { Linoleic acid (18:2n6) with increasing } \\
\text { inclusion level. } \\
\text { EPA in the muscle of fish fed with } \\
\text { MWM at 50\% in the diet. } \\
\text { DHA in muscle as inclusion levels } \\
\text { increased. } \\
\text { Palmitic acid (16:0) in the muscle of } \\
\text { fish fed with MWM at 50\% in the diet. } \\
\text { Alpha-linolenic acid (18:3n3) in fish } \\
\text { fed the control diet and 25\% MWM. } \\
\text { AI and TI in fish fed with 50\% MWM } \\
\text { in the diet. }\end{array}$ & $\begin{array}{l}(\leftrightarrow) \\
(\uparrow) \\
(\downarrow) \\
(\uparrow) \\
(\downarrow) \\
(\downarrow) \\
(\uparrow) \\
(\uparrow) \\
(\uparrow)\end{array}$ & $\begin{array}{c}\text { Iaconisi et al. } \\
\text { (2017) }\end{array}$ \\
\hline $\begin{array}{l}\text { Juvenile Mandarin } \\
\quad \text { fish } \\
\text { (Siniperca scherzeri) }\end{array}$ & $\begin{array}{c}10,20 \text { and } \\
30 \%\end{array}$ & Filet & $\begin{array}{l}\text { Moisture, crude protein, crude lipid, } \\
\text { mineral matter. } \\
\text { Essential amino acids. } \\
\text { Myristic acid (C14: } 0 \text { ), palmitic acid } \\
\text { (C16:0), stearic acid (C18:0), including } \\
\text { 30\% inclusion compared to the control } \\
\text { group. } \\
\text { Palmitoleic acid, oleic acid, linoleic } \\
\text { acid with increasing inclusion level. }\end{array}$ & $\begin{array}{l}(\leftrightarrow) \\
(\leftrightarrow) \\
(\uparrow) \\
(\uparrow)\end{array}$ & $\begin{array}{c}\text { Sankian et al. } \\
\text { (2018) }\end{array}$ \\
\hline $\begin{array}{l}\text { Juvenis de Rockfish } \\
\text { (Sebastes schlegeli) }\end{array}$ & $\begin{array}{c}8,16,24 \text { and } \\
32 \%\end{array}$ & $\begin{array}{l}\text { Whole body } \\
\text { and muscle }\end{array}$ & $\begin{array}{l}\text { Moisture, protein, lipid e mineral } \\
\text { matter. } \\
\text { Essencial amino acids. }\end{array}$ & $\begin{array}{l}(\leftrightarrow) \\
(\leftrightarrow)\end{array}$ & $\begin{array}{l}\text { Khosravi et } \\
\text { al. }(2018)\end{array}$ \\
\hline $\begin{array}{l}\text { Rainbow trout } \\
\text { (Oncorhynchus } \\
\text { mykiss) }\end{array}$ & 25 and $50 \%$ & $\begin{array}{c}\text { Raw filet and } \\
\text { cooked filet }\end{array}$ & $\begin{array}{l}\text { Moisture, crude protein, total lipids and } \\
\text { mineral matter. } \\
\text { The sum of MUFA and oleic acid } \\
\text { (C18:1n9) with increasing levels of } \\
\text { inclusion of MWM in the diet. } \\
\text { PUFA n- } 6 \text { and linoleic acid (C18:2n6) } \\
\text { with increasing inclusion levels. } \\
\text { PUFA n-3 with increasing levels of } \\
\text { inclusion of MWM in the diet. Total } \\
\text { percentage of SFA in cooked fish fillets } \\
\text { fed with 50\% MWM inclusion in the } \\
\text { diet. } \\
\text { Palmitic acid in raw and cooked fish } \\
\text { fillets fed with inclusion of MWM in } \\
\text { the diet. }\end{array}$ & $\begin{array}{l}(\leftrightarrow) \\
(\uparrow) \\
(\uparrow) \\
(\downarrow) \\
(\uparrow) \\
(\uparrow)\end{array}$ & $\begin{array}{l}\text { Iaconisi et al. } \\
\text { (2018) }\end{array}$ \\
\hline $\begin{array}{l}\text { Gilthead sea bream } \\
\text { (Sparus aurata L.) }\end{array}$ & & Muscle & $\begin{array}{l}\text { Lysine, alanine and leucine in fish fed } \\
\text { with MWM at } 50 \% \text { in the diet. } \\
\text { Histidine and phenylalanine in fish fed } \\
\text { with MWM in the diet. }\end{array}$ & $\begin{array}{l}(\uparrow) \\
(\downarrow)\end{array}$ & \\
\hline $\begin{array}{l}\text { Rainbow trout } \\
\text { (Oncorhynchus } \\
\text { mykiss) }\end{array}$ & 25 and $50 \%$ & Muscle & $\begin{array}{l}\text { Leucine, alanine, cystine, proline, } \\
\text { taurine and tyrosine with increasing } \\
\text { MWM inclusion level. } \\
\text { Histidine, methionine, threonine and } \\
\text { asparagine + aspartic acid with } \\
\text { increasing inclusion of MWM in the } \\
\text { diet. } \\
\text { Glutamine + glutamic acid in fish fed } \\
\text { 50\% MWM in the diet. }\end{array}$ & $(\downarrow)$ & $\begin{array}{l}\text { Iaconisi et al. } \\
\text { (2019) }\end{array}$ \\
\hline $\begin{array}{l}\text { Rainbow trout } \\
\text { (Oncorhynchus } \\
\text { mykiss) }\end{array}$ & $\begin{array}{c}5,7.5,15 \text { and } \\
25 \%\end{array}$ & Whole body & $\begin{array}{l}\text { Moisture, protein, fat, mineral matter, } \\
\text { phosphorus and energy. } \\
\text { Protein, phosphorus and energy } \\
\text { retention with increased inclusion. } \\
\text { Fat retention. }\end{array}$ & $\begin{array}{l}(\leftrightarrow) \\
(\uparrow) \\
(\leftrightarrow)\end{array}$ & $\begin{array}{l}\text { Rema et al. } \\
\text { (2019) }\end{array}$ \\
\hline
\end{tabular}




$\begin{array}{cccccc}\text { Nile tilapia } & 5,10,15 \text { and } \\ \begin{array}{c}\text { (Oreochromis } \\ \text { niloticus) }\end{array} & 20 \% & \text { Whole body } & \begin{array}{l}\text { Crude protein and mineral matter. } \\ \text { Positive correlation between dry matter } \\ \text { and crude lipid, both increasing with } \\ \text { the level of inclusion. }\end{array} & (\leftrightarrow) & \begin{array}{c}\text { Tubin et al. } \\ (2020)\end{array}\end{array}$

$(\uparrow)$ increase; $(\downarrow)$ decrease; $(\leftrightarrow)$ no change. Ecosapentaenoic acid (EPA), docosahexaenoic acid (DHA), docosapentaenoic acid (DPA), saturated fatty acid (SFA), monounsaturated fatty acid (MUFA), polyunsaturated fatty acid (PUFA), atherogenic index (AI), thrombogenic index (TI). Source: Authors.

\subsection{Immunological parameters and antioxidant activity}

Fish, like mammals, have innate and acquired immune responses (Iwasaki \& Medzhitov, 2010; Zhu et al., 2013), their immune status can be widely affected by the nutrients and ingredients in their diet (Kiron, 2012). Unlike potential alternative sources of protein, mealworm meal (MWM) has a high protein and fat content, in addition, it also has minerals (zinc and selenium), vitamins (B2, B5, B7, B9), chitin peptides and antimicrobial (AMPs) (Liu et al., 2005; Rumpold \& Schluter, 2013). AMPs can be found in virtually all groups of organisms and can promote innate immunity and eliminate rival microorganisms in the race for the same environment (Nawrocki et al., 2014). There are different mechanisms by which AMPs can act, but it is known that permeation followed by target cell interruption and death is the most common, unlike antibiotics that interact with a specific protein (Nascimento et al., 2003; König et al., 2015). Thus, this mechanism prevents organisms from showing resistance to peptides, offering the possibility of a new class of therapeutic agents that are complementary to existing antibiotics (Zasloff, 2002; Nascimento et al., 2003; König et al., 2015). The main effects of the inclusion of MWM in the diet on the immunological parameters and antioxidant activity of fish can be seen in Table 4 .

Antioxidant capacity is essential for maintaining the complex immune system of fish, including both enzymatic and non-enzymatic antioxidant activities (Song et al., 2018). Antioxidant enzymes including superoxide dismutase (SOD), catalase (CAT) and glutathione reductase (GR) are the first line of the body's enzyme defense mechanism against free radicals (Deng et al., 2015). SOD can catalyze the reduction of superoxide anion $\left(\mathrm{O}_{2}\right)$ for hydrogen peroxides $\left(\mathrm{H}_{2} \mathrm{O}_{2}\right)$, that is, by digging free radicals (Dorval et al., 2003; Achuba \& Osakwe, 2003). The results found by Su et al. (2017) for MDA and SOD suggest that MWM in the diet may improve the antioxidant functions of yellow catfish (Pelteobagrus fulvidraco).

According to the findings of Henry et al., (2018a), the ability of mealworm to improve the antioxidant defense system in the proximal and distal sections of the intestine of fish such as rainbow trout (Oncorhynchus mykiss) can be confirmed. The increase in antioxidant activity with the inclusion of insects in the diet may be due to their chitin content or other bioactive compounds (Ngo \& Kim, 2014), as these substances can have an immunostimulating activity (Henry et al., 2018a). According to $\mathrm{Su}$ et al. (2017), the level of food inclusion of at least $18 \%$ MWM improved the immune response and resistance of yellow catfish (Pelteobagrus fulvidraco) against Edwardsiella ictaluri, without any negative effect on fish growth. According to the authors, the inclusion of MWM has been shown to be promising as an alternative protein source to replace fishmeal and it is recommended to include at least $18 \mathrm{~g}$ of MWM per $100 \mathrm{~g}$ of diet in catfish feed (Su et al., 2017).

The inflammatory response evaluated by quantifying ceruloplasmin and serum nitric oxide tends to be reduced in rainbow trout by the inclusion of MWM in the diet, which suggests a good state of health (Henry et al., 2018a). The opposite occurred with the activity of seeric myelloxidase, which increased significantly in rainbow trout fed with the highest level of inclusion MWM compared to the other groups (Henry et al. 2018a).

Myeloperoxidase (MPO) is linked to the inflammatory process, and is also directly related to the activity of respiratory rupture, as it detoxifies hydrogen peroxide produced by fish blood cells. While MPO activity was reduced in European sea bass (Dicentrarchus labrax), MPO activity increased in rainbow trout. Thus, the authors state that MPO activity is stronger in rainbow trout than in European sea bass, and may play an important role in the protection of these fish species 
(Henry et al., 2018a; Henry et al., 2018b).

Lysozyme is an adaptive immune response marker against invasive infection (Saurabh \& Sahoo, 2008). Diets fed yellow catfish supplemented with MWM showed high linsozyme activity compared to the control group, especially after challenge with Edwardsiella ictaluri (Su et al., 2017).

IgM (immunoglobulin M) and MHC (major histocompatibility complex) products are important components of the adaptive immune system in fish (Rauta et al., 2012). IgM is the main antibody of the primary response, as well as an essential part of the adaptive immune response of fish (Magnadóttir, 1998). MHC plays the important role of transporting peptide antigens to T lymphocytes to the adaptive immune system in fish (Kurtz et al. 2004, Dijkstra et al., 2013).

According to $\mathrm{Su}$ et al. (2017), the partial replacement of fishmeal by MWM can significantly increase the transcriptional level of IgM in the liver and the yellow catfish spleen, in addition to the plasma level of IgM, indicating that IgM, MHC II and IL-2 (interleukin 2 - protein that induces the maturation of B lymphocytes and T cells) were involved in the alteration of the immunological status of the yellow catfish, and MWM feeding could have promoted, in part, the adaptive immune response of the yellow catfish. Immunological responses may also have been triggered by the presence of chitin found in the larvae exoskeletons T. molitor (Su et al., 2017), since chitin has complex effects on innate and adaptable immune responses, including the ability to recruit and activate innate immune cells and induce the production of cytokines and chemokines through a variety of cell surface receptors (Lee et al., 2008).

Implicit results in MWM may affect the antioxidant capacity of fish. This was consistent with that observed by Song et al., (2018), where the post-challenge survival with Vibrio harveyi was higher for fish fed the $18.75 \%$ MWM diet, however, when the replacement rate exceeded $18.75 \%$, the fish presented lower rates survival. Thus, the authors suggest that an ideal level of inclusion of MWM can strengthen the immunity of juveniles gentile rumupeiro (E. lanceolatus $\mathrm{x}$ E. fuscoguttatus) and improve their resistance to $V$. Harveyi.

In fish, as in other vertebrates, the population of the gastrointestinal microbiota is entirely correlated with the diet and functions of the gastrointestinal tract (GIT), as well as with the health status and performance of the animals (Józefiak et al., 2019). The increase in the number of Bacillus spp. in fish TGI is a potentially positive effect on intestinal health status, being one of the most used probiotics in aquaculture (Geraylou et al., 2013). In addition, several studies have demonstrated the immunomodulatory effects of Bacillus spp., including the improvement of phagocytosis in Catla catla and resistance to changes in salinity, temperature, ammonia and pH by Acipenser percicus larvae (Faramarzi et al., 2012; Geraylou et al., 2013). In a study with Siberian sturgeon (Acipenser baerii Brandt, 1869), the population of Bacillus spp. increased in treatments with insects (Hermitia illucens and Tenebrio molitor), which may suggest an improvement in the beneficial bacterial barrier against fish pathogens and have the potential to increase the immunomodulatory effects of host defense (Józefiak et al., 2019). 
Table 4. Immunological parameters and antioxidant activity in fish fed with inclusion of mealworm meal (MWM) in the diet.

\begin{tabular}{|c|c|c|c|c|}
\hline Species & $\begin{array}{c}\text { MWM inclusion } \\
\text { level }\end{array}$ & Evaluated parameter & $\begin{array}{l}\text { MWM inclusion } \\
\text { response }\end{array}$ & Reference \\
\hline $\begin{array}{l}\text { Nile tilapia } \\
\text { (Oreochromis } \\
\text { niloticus) }\end{array}$ & 21 and $43 \%$ & $\begin{array}{l}\text { SOD activity with increasing inclusion level. } \\
\text { CAT, GPx, GR, glutathione transferase and DT- } \\
\text { diaphoresis. }\end{array}$ & $\begin{array}{l}(\downarrow) \\
(\leftrightarrow)\end{array}$ & $\begin{array}{c}\text { Sánchez-Muros } \\
\text { et al. (2015) }\end{array}$ \\
\hline $\begin{array}{l}\text { Yellow catfish } \\
\text { (Pelteobagrus } \\
\text { fulvidraco) }\end{array}$ & 9,18 and $27 \%$ & $\begin{array}{l}\text { MDA in fish supplemented with MWM compared } \\
\text { to the control group. } \\
\text { SOD, lysozyme, C } 3 \text { and plasma IgM activity after } \\
\text { challenge with } E \text {. ictaluri in groups with inclusion } \\
\text { of MWM compared to pre-challenge. } \\
\text { IL-1 in the liver of fish fed with MWM at } 9 \% \text { and } \\
\text { IgM in the liver of fish fed with MWM at } 9 \text { and } \\
18 \% \text {, in the pre-challenge. } \\
\text { MHC II in the spleen of fish fed with } 9 \text { and } 18 \% \\
\text { MWM and of the IgM in the spleen of fish fed } \\
\text { with MWM at } 9,18 \text { and } 27 \%, \text { pre-challenge. } \\
\text { Genes related to the immune system of MHC II, } \\
\text { IgM and HE, in the pre-challenge. } \\
\text { MHC II and IL-1 in the liver of fish fed with } 9 \% \\
\text { inclusion. } \\
\text { Transcription of HE in the liver of fish fed with } \\
18 \% \text { inclusion. } \\
\text { IL-1 in the spleen post challenge in fish fed with } \\
18 \% \text { inclusion. } \\
\text { Genes related to the immune system of MHC II } \\
\text { and CypA post-challenge in fish fed with } \\
\text { inclusion of MWM in the diet. } \\
\text { MHC II, IL-1, CypA, IgM and HE post challenge. } \\
\text { Bacterial resistance of fish fed with inclusion of } \\
\text { MWM in the diet. }\end{array}$ & $\begin{array}{l}(\uparrow) \\
(\uparrow) \\
(\leftrightarrow) \\
(\uparrow) \\
(\uparrow) \\
(\uparrow) \\
(\uparrow) \\
(\leftrightarrow) \\
(\uparrow)\end{array}$ & Su et al. (2017) \\
\hline $\begin{array}{l}\text { European sea bass } \\
\text { (Dicentrarchus } \\
\text { labrax) }\end{array}$ & $24.75 \%$ & $\begin{array}{l}\text { Serum activity of ceruloplasmin, MPO and nitric } \\
\text { oxide concentration in fish fed MWM with or } \\
\text { without exogenous enzymes. } \\
\text { Anti-Gram negative bacteriolytic activity in the } \\
\text { group fed MWM + exogenous protease in the diet. } \\
\text { Lysozyme activity. } \\
\text { Trypsin inhibition activity in the fed group with } \\
\text { inclusion of MWM and MWM + exogenous } \\
\text { carbohydrates in the diet. }\end{array}$ & $\begin{array}{l}(\downarrow) \\
(\leftrightarrow) \\
(\uparrow)\end{array}$ & $\begin{array}{l}\text { Henry et al. } \\
\text { (2018b) }\end{array}$ \\
\hline $\begin{array}{l}\text { Juvenile Pearl } \\
\text { Gentian grouper } \\
\text { (E. lanceolatus } \mathrm{x} \\
\text { E. fuscoguttatus) }\end{array}$ & $\begin{array}{c}2.5,5,7.5,10 \\
\text { and } 12.5 \%\end{array}$ & $\begin{array}{l}\text { GR activity in the liver of fish fed with } 2.5 \% \\
\text { inclusion, compared to the other groups. } \\
\text { SOD activity in the liver of fish fed } 7.5 \% \text { MWM } \\
\text { in the diet, compared to the control group and at } \\
10 \% \text { inclusion. } \\
\text { MDA concentration in the liver of fish fed with } \\
2.5 \text { and } 7.5 \% \text { inclusion, compared to groups with } \\
\text { inclusion of MWM. } \\
\text { Relative percentage survival of fish fed with } 7.5 \% \\
\text { inclusion. }\end{array}$ & $(\downarrow)$ & $\begin{array}{l}\text { Song et al. } \\
\text { (2018) }\end{array}$ \\
\hline $\begin{array}{c}\text { Juvenile } \\
\text { Mandarin fish } \\
\text { (Siniperca } \\
\text { scherzeri) }\end{array}$ & 10,20 and $30 \%$ & $\begin{array}{l}\text { Lysozyme and GPx with increasing inclusion } \\
\text { level. } \\
\text { MPO, SOD and total immunoglobulin. }\end{array}$ & $\begin{array}{l}(\uparrow) \\
(\leftrightarrow)\end{array}$ & $\begin{array}{c}\text { Sankian et al. } \\
\text { (2018) }\end{array}$ \\
\hline
\end{tabular}




\begin{tabular}{|c|c|c|c|c|}
\hline $\begin{array}{l}\text { Rainbow trout } \\
\text { (Oncorhynchus } \\
\text { mykiss) }\end{array}$ & 25 and $50 \%$ & $\begin{array}{l}\text { SOD and CAT activity in the proximal intestine } \\
\text { of fish fed MWM at } 50 \% \text { inclusion. } \\
\text { SOD and CAT activity in the distal intestine of } \\
\text { fish fed with } 25 \% \text { inclusion. } \\
\text { GPx in the pyloric cecum with increasing } \\
\text { inclusion level. } \\
\text { GR and G6PD in the proximal and distal bowel } \\
\text { with increasing inclusion level. } \\
\text { LPO in the proximal and distal portion of the } \\
\text { intestine with increasing inclusion. } \\
\text { Lysozyme activity, bacterial activity, } \\
\text { ceruloplasmin and nitric oxide. } \\
\text { Time to death of } 50 \% \text { of bacteria with increasing } \\
\text { inclusion level. } \\
\text { MPO activity in fish fed with 50\% inclusion } \\
\text { compared to other groups. } \\
\text { Trypsin inhibition in fish fed with MWM at } 50 \% \\
\text { in the diet. }\end{array}$ & $\begin{array}{l}(\uparrow) \\
(\uparrow) \\
(\uparrow) \\
(\uparrow) \\
(\downarrow) \\
(\leftrightarrow) \\
(\downarrow) \\
(\uparrow) \\
(\uparrow)\end{array}$ & $\begin{array}{l}\text { Henry et al. } \\
\quad(2018 \mathrm{a})\end{array}$ \\
\hline $\begin{array}{l}\text { Rainbow trout } \\
\text { (Oncorhynchus } \\
\text { mykiss) }\end{array}$ & 5,10 and $20 \%$ & $\begin{array}{l}\text { In amino acid catabolic enzymes such as ALT, } \\
\text { AST, glutamate dehydrogenase. } \\
\text { In lipogenic enzymes such as G6PD, malic } \\
\text { enzyme and fatty acid synthase. }\end{array}$ & $\begin{array}{l}(\leftrightarrow) \\
(\leftrightarrow)\end{array}$ & $\begin{array}{l}\text { Chemello et al. } \\
\text { (2020) }\end{array}$ \\
\hline
\end{tabular}

\subsection{Hematological and biochemical parameters}

The levels of aminotransferase alanine (ALT) and aminotransferase aspartate (AST) serum are sensitive indicators of liver damage, the elevation of which may reflect liver damage (Lin et al., 1990; Mohieldein et al., 2013; Song et al., 2018). Some studies on the effects of the use T. Molitor on fish hematology and biochemical parameters are presented in Table 5.

After replacing fishmeal with MWM, reductions in glucose were found in fish fed the 6.25, 12.5, 18.75 and $25 \%$ MWM diets, indicating that MWM can improve glucose absorption rate and decrease blood glucose concentration. The higher glucose absorption rate demonstrated that MWM can promote feed efficiency and then improve growth performance.This may be the reason why gentian garoubre juveniles fed $12.5 \% \mathrm{MWM}$ in the diet had a higher rate of weight gain and lower feed conversion ratio, since glucose concentration in this diet was lower (Song et al., 2018).

The sarid concentration of triglycerides showed a decreasing trend with the inclusion of MWM in the diet. The results suggested that MWM could modify serum levels of triglycerides and total cholesterol (Song et al., 2018). This was supported by previous studies, where linoleic acid could promote the degradation of cholesterol and triglycerides and represented $35.88 \%$ in MWM fatty oil (Li et al., 2008; Liu et al., 2010). 
Table 5. Hematological and biochemical parameters of fish fed with the inclusion of mealworm meal (MWM) in the diet.

\begin{tabular}{|c|c|c|c|c|}
\hline Species & $\begin{array}{c}\text { MWM inclusion } \\
\text { level }\end{array}$ & Evaluated parameter & $\begin{array}{l}\text { MWM inclusion } \\
\text { response }\end{array}$ & Reference \\
\hline $\begin{array}{l}\text { Juvenile Rockfish } \\
\text { (Sebastes schlegeli) }\end{array}$ & $8,16,24$ and $32 \%$ & $\begin{array}{l}\text { Triglycerides with increased inclusion level. } \\
\text { Total cholesterol, AST, ALT, ALP and total } \\
\text { protein with inclusion. }\end{array}$ & $\begin{array}{l}(\downarrow) \\
(\leftrightarrow)\end{array}$ & $\begin{array}{l}\text { Khosravi et al. } \\
\text { (2018) }\end{array}$ \\
\hline $\begin{array}{l}\text { Juvenile Pearl } \\
\text { Gentian grouper } \\
\text { (E. lanceolatus } \mathrm{x} E \text {. } \\
\text { fuscoguttatus) }\end{array}$ & $\begin{array}{c}2.5,5,7.5,10 \text { and } \\
12.5 \%\end{array}$ & $\begin{array}{l}\text { Total protein from fish fed } 7.5,10 \text { and } 12.5 \% \\
\text { MWM, compared to control and } 2.5 \text { and } 5 \% \\
\text { MWM. } \\
\text { Glucose from fish fed with } 12.5 \% \text { MWM, } \\
\text { compared to the other groups. } \\
\text { Total cholesterol of fish fed } 12.5 \% \text { and a } \\
\text { decrease in inclusion of } 7.5 \% \text { MWM. } \\
\text { Triglycerides with increased dietary MWM. } \\
\text { ALT in fish fed } 2.5 \% \text { followed by } 5 \text { and 10\% } \\
\text { inclusions. } \\
\text { AST in fish fed with } 2.5 \text { and 5\% inclusion. }\end{array}$ & $\begin{array}{l}(\downarrow) \\
(\uparrow) \\
(\uparrow) \\
(\downarrow) \\
(\uparrow) \\
(\uparrow)\end{array}$ & Song et al. (2018) \\
\hline $\begin{array}{l}\text { Juvenile Mandarin } \\
\text { fish } \\
\text { (Siniperca } \\
\text { scherzeri) }\end{array}$ & 10,20 and $30 \%$ & $\begin{array}{l}\text { Total cholesterol with increased inclusion level. } \\
\text { Total protein, triglycerides, aspartate } \\
\text { aminotransferase, alanine aminotransferase, } \\
\text { albumin and alkaline phosphatase. }\end{array}$ & $(\downarrow)$ & $\begin{array}{l}\text { Sankian et al. } \\
\qquad(2018)\end{array}$ \\
\hline $\begin{array}{l}\text { Nile tilapia } \\
\text { (Oreochromis } \\
\text { niloticus) }\end{array}$ & $5,10,15$ and $20 \%$ & $\begin{array}{l}\text { Cholesterol, glucose, hematocrit, erythrocytes, } \\
\text { protein, leukocytes, thrombocytes, } \\
\text { lymphocytes, neutrophils and monocytes. }\end{array}$ & $(\leftrightarrow)$ & Tubin et al. (2020) \\
\hline
\end{tabular}

$(\uparrow)$ increase; $(\downarrow)$ decrease; $(\leftrightarrow)$ no change. ALP (alkaline phosphatase), ALT (alanine aminotransferase), AST (aspartate aminotransferase). Source: Authors.

\section{Future Directions}

The divergence between the results found in the studies addressed in this review in relation to the levels of inclusion of mealworm meal as an alternative source of protein in fish feeding can be attributed to the various methodological differences between the studies, including composition, diet formulation, fish species and rearing conditions. In general, with the research conducted so far, the inclusion of MWM in fish diets showed good results. To ensure the safety and nutritional quality of diets containing mealworm, some factors have not yet been evaluated:

- Analysis of the amount of chitin present in larvae as a possible factor of interference in digestibility or as an overestimation factor of the protein of this product, as well as a potential beneficial property that chitin may present. The immunomodulatory action of chitin is still very complex and size-dependent (Henry et al., 2018b). Large chitin polymers are considered inert, smaller pro-inflammatory fragments, while even smaller fragments may be anti-inflammatory (Lee et al., 2008).

- Fat extraction for the use of defatted larvae, which allows concentrating the protein, in addition to ensuring the quality of the product for longer, reducing the lipid oxidation reactions.

- Investigation of the existence of toxic substances that can trigger responses by the immune system of fish.

- Evaluation of sustainable substrates for larvae production, aiming at better composition and viability of production.

- Evaluate different forms of processing of larvae in order to avoid nutrient loss by oxidation of fats or through drying.

Finally, the higher cost of fish production is linked to your nutrition. In this context, the Tenebrio molitor larvae have 
great potencial to compet with other ingredients used to manufacture fish feed, from large-scale production, reducing the cost of production.

\section{References}

Achuba, F. I. \& Osakwe, S. A. (2003). Petroleum - induced free radical toxicity in African catfish (Clarias gariepinus). Fish. Physiol. Biochem., $29,97-103$.

Aguilar-Miranda, E. D., López, M. G., Escamilla-Santana, C. \& Barba De La Rosa, A.P. (2002). Characteristics of maize flour tortilla supplemented with ground Tenebrio molitor larvae, J. Agric. Food Chem., 50 (1): 192-195.

Barone, R. S. C. (2017). Feed is the main input for aquaculture production. Aquaculture assets. CNA Brazil. Year 3. Ed.13.

Barroso, F.G., de Haro, C., Sánchez-Muros, M-J., Venegas, E., Martínez-Sánchez, A. \& Pérez-Bañón, C. (2014). The potential of various insect species for use as food for fish. Aquaculture 422-423, 193-201. https://doi.org/10.1016/j.aquaculture.2013.12.024

Basto, A., Matos, E. \& Valente, L. M. P (2020). Nutritional value of different insect larvae meals as protein sources for European sea bass (Dicentrarchus labrax) juveniles. Aquaculture 521, 735085. https://doi.org/10.1016/j.aquaculture.2020.735085

Bednářová, M., Borkovcová, M., Mlček, J., Rop, O. \& Zeman, L. (2013). Edible insects - species suitable for entomophagy under condition of Czech Republic. Acta Univ. Agric. Silvic. Mendel. Brun, 61, 587-593. https://doi.org/10.11118/actaun201361030587

Belforti, M., Gai, F., Lussiana, C., Renna, M., Malfatto, V., Rotolo, L., De Marco, M., Dabbou, S., Schiavone, A., Zoccarato, I. \& Gasco, L. (2015). Tenebrio molitor meal in rainbow trout (Oncorhynchus mykiss) diets: effects on animal performance, nutrient digestibility and chemical composition of fillets. Ital. $J$. Anim. Sci. 14 (4), 4170. https://doi.org/10.4081/ijas.2015.4170

Berggren, A., Jansson, A. \& Low, M. (2019). Approaching ecological sustainability in the emerging insects-as-food industry. Trends Ecol. Evol. $34,132-138$. https://doi.org/10.1016/j.tree.2018.11.005

Beveridge, T. J. (1999). Structures of Gram-negative cell walls and their derived membrane vesicles. J. Bacteriol. 181, 4725-4733.

Bovera, F., Marono, S., Di Meo, C. Piccolo, G., Iannaccone, F. \& Nizza, A. (2010). Effect of mannanoligosaccharides supplementation on caecal microbial activity of rabbits. Animal, 9, 1522-1527. Doi: 10.1017/S1751731110000558

Bovera, F., Loponte, R., Marono, S., Piccolo, G., Parisi, G., Iaconisi, V., Gasco, L. \& Nizza, A. (2016). Use of Tenebrio molitor larvae meal as protein source inbroiler diet: effect on growth performance, nutrient digestibility, and carcass and meat traits. J. Anim. Sci. 94 (2), $639-647$. http://dx.doi.org/10.2527/jas2015-9201

Celik, M., Diler, A. \& Kuçukgulmez, A. (2005). A comparison of the proximate compositions and fatty acid profi les of zander (Sander lucioperca) from two different regions and climatic conditions. Food Chemistry, Champaign. 92(4):637-641.

Chemello, G., Renna, M., Caimi, C., Guerreiro, I., Oliva-Teles, A., Enes, P., Biasato, I., Schiavone, A., Gai, F. \& Gasco, L. (2020). Partially Defatted Tenebrio molitor Larva Meal in Diets for Grow-Out Rainbow Trout, Oncorhynchus mykiss (Walbaum): Effects on Growth Performance, Diet Digestibility and Metabolic Responses. Animals, 10, 229. https://doi.org/10.3390/ani10020229

Choi, B. D., Wong, N. A. K. \& Auh, J.-H. (2017). Defatting and sonication enhances protein extraction from edible insects. Korean J. Food Sci. Anim. Resour., 37, 955-961. Doi: 10.5851/kosfa.2017.37.6.955

Danulat, E. (1987). Digestibility of chitin in cod, Gadus morhua, in vivo. Helgolander Meeresuntersuch, 41, 425-436.

De Francesco, M., Parisi, G., Pérez-Sánchez, J., Gómez-Réqueni, P., Médale, F., Kaushik, S.J., Mecatti, M. \& Poli, B.M. (2007). Effect of high-level fish meal replacement by plant proteins in gilthead sea bream (Sparus aurata) on growth and body/fillet quality traits. Aquac. Nutr. 13, 361-372. https://doi.org/10.1111/j.1365-2095.2007.00485.x

De Marco, M., Martínez, S., Hernandez, F., Madrid, J., Gai, F., Rotolo, L., Belforti, M., Bergero, D., Katz, H., Dabbou, S., Kovitvadhi, A., Zoccarato, I., Gasco, L. \& Schiavone, A. (2015). Nutritional value of two insect meals (Tenebrio molitor and Hermetia illucens) for broiler chickens: apparent nutrient digestibility, apparent ileal amino acid digestibility and apparent metabolizable energy. Anim. Feed Sci. Technol. 209, 211-218. https://doi.org/10.1016/j.anifeedsci.2015.08.006

Deng, J., Mai, K., Chen. L., Mi, H. \& Zhang, L. (2015). Effects of replacing soybean meal with rubber seed meal on growth, antioxi dant capacity, nonspecific immune response, and resistance to Aeromonas hydrophila in tilapia (Oreochromis niloticus x O. aureus). Fish \& Shellfish Immunology, $44,436-444$. https://doi.org/10.1016/j.fsi.2015.03.018

Dernekbaşi, S. (2012). Digestibility and Liver Fatty Acid Composition of Rainbow Trout (Oncorhynchus mykiss) Fed by Graded Levels of Canola Oil. Turkish Journal of Fisheries and Aquatic Sciences 12, 105-113. 10.4194/1303-2712-v12_1_13

Desvaux, M., Dumas, E., Chafsey, I. \& Hebraud, M. (2006). Protein cell surface display in gram-positive bacteria: from single protein to macromolecularprotein structure. FEMS Microbiol. Lett. 256, 1-15, http://dx.doi.org/10.1111/j.1574-6968.2006.00122.x

Dijkstra, J.M., Grimholt, U. Leong, J., Koop, B.F. \& Hashimoto, K. (2013). Analysis of class II MHC gene data in teleost fish genomes reveals the dispensability of the DM peptide loading system in most vertebrates. BMC Evol. Biol., 13, p. 260.

Dorval, J., Leblond, V. S. \& Hontela, A. (2003). Oxidative stress and loss of cortisol secretion in adrenocortical cells of rainbow trout (Oncorhynchus mykiss) exposed in vitro to endosulfan, an organochlorine pesticide. Aquat. Toxicol., 63, 229-241. https://doi.org/10.1016/S0166-445X(02)00182-0 
Esteban, M. A., Cuesta, A., Ortuño, J. \& Meseguer, J. (2001). Immunomodulatory effects of dietary intake of chitin on gilthead seabream (Sparus aurata L.) innate immune system. Fish Shellfish Immunol., 11, 303-315. https://doi.org/10.1006/fsim.2000.0315

FAO (2013). Food and Agriculture Organization of the United Nations. Edible insects: future prospects for food and feed security. Fisheries and Aquaculture Department, Rome, 171p.

FAO (2020). The State of World Fisheries and Aquaculture 2020. Sustainability in action. Rome. https://doi.org/10.4060/ca9229en

Faramarzi, M., Jafaryan, H., Roozbehfar, R., Jafari, M., Rashidi, Y., \& Biria, M. (2012). Influences of probiotic bacilli via bioencapsulated Daphnia magna on resistance of Persian sturgeon larvae against challenge tests. Glob Vet. 8 (4), 421-5.

Ferreira, M. S., Aride, P. H. R., Silva, M. N. P. \& Val, A. L. (2013). Dietary protein and exercise training effects on the physiological and zootechnical parameters of matrinchã (Brycon amazonicus, Günther 1869). Acta Amazon. 43(4), 429-446.

Finke, M. D. (2002). Complete nutriente composition of commercially raised invertebrates used as food for insectivores. Zoo Biology, 21(3), $269-285$.

Fontes, T. V., Oliveira, K. R. B., Almeida, I. L. G., Orlando, T. M., Rodrigues, P. B., Costa, D. V. \& Rosa, P. V. (2019). Digestibility of Insect Meals for Nile Tilapia Fingerlings. Animals, 9, 181. https://doi.org/10.3390/ani9040181

Fraanje, W. \& Garnett, T. (2020). Soy: food, feed, and land use change. (Foodsource: Building Blocks). Food Climate Research Network, University of Oxford. https://foodsource.org.uk/sites/default/files/building-blocks/pdfs/fcrn_building_block_-_soy_food_feed_and_land_use_change.pdf. Accessed on October 13, 2020.

García-Romero, J., Ginés, R., Izquierdo, M.S., Haroun, R., Badilla, R. \& Rabaina, L. (2014). Effect of dietary substitution of fish meal for marine crab and echinoderm meals on growth performance, ammonia excretion, skin colour, and flesh quality and oxidation of red porgy (Pagrus pagrus). Aquaculture 422, 239-248. https://doi.org/10.1016/j.aquaculture.2013.11.024

Gasco, L., Henry, M., Piccolo, G., Marono, S., Gai, F., Renna, M., Lussiana, C., Antonopoulou, E., Mola, P. \& Chatzifotis, S. (2016). Tenebrio molitor meal in diets for European sea bass (Dicentrarchus labrax L.) juveniles: growth performance, whole body composition and in vivo apparent digestibility. Anim. Feed Sci. Technol., 220, 34-45. https://doi.org/10.1016/j.anifeedsci.2016.07.003

Gatlin, D. M., Barrows, F. T., Brown, P., Dabrowski, K., Gaylord, T. G., Hardy, R. W., Herman, E., Hu, G., Krogdahl, Å., Nelson, R., Overturf, K., Rust, M., Sealey, W., Skonberg, D., Souza, E. J., Stone, D., Wilson, R., \& Wurtele, E. (2007). Expanding the utilization of sustainable plant products in aquafeeds: A review. Aquaculture Research, 38 (6), 551-579. https://doi.org/10.1111/j.1365-2109.2007.01704.x

Gause, B. R. \& Trushenski, J. T. (2013). Sparing fish oil with beef tallow in feeds for rainbow trout: effects of inclusion rates and finishing on production performance and tissue fatty acid composition. N. Am. J. Aquacult. 75, 495-511. https://doi.org/10.1080/15222055.2013.811134

Geraylou, Z., Souffreau, C., Rurangwa, E., Maes, G. E., Spanier, K. I., Courtin, C. M., Delcour, J. A., Buyse, J., Ollevier, F. (2013). Prebiotic effects of arabinoxylan oligosaccharides on juvenile Siberian sturgeon (Acipenser baerii) with emphasis on the modulation of the gut microbiota using 454 pyrosequencing. FEMS Microbiol Ecol. 86 (2): 357-71. https://doi.org/10.1111/1574-6941.12169

Ghosh, S., Lee, S. M., Jung, C. \& Meyer-Rochow, V. B. (2017). Nutritional composition of five commercial edible insects in South Korea. J. Asia-Pac. Entomol., 20, 686-694. https://doi.org/10.1016/j.aspen.2017.04.003

Glencross, B. D., Booth, M. \& Allan, G. L. (2007). A feed is only as good as its ingredients - a review of ingredient evaluation strategies for aquaculture feeds. Aquac. Nutr. 13, 17-34. https://doi.org/10.1111/j.1365-2095.2007.00450.x

Gutowska, M. A., Drazen, J. C. \& Robison, B. H. (2004). Digestive chitinolytic activity in marine fishes of Monterey Bay, California. Comp. Biochem. Physiol. 139A, 351-358.

Hardouin, J. \& Mahoux, G., 2003. Zootechnie d'insectes - Elevage et utilisation au bénéfice de l'homme et de certains animaux. Bureau pour l'Echange et la Distribution de l'Information sur le Mini-élevage (BEDIM), $164 \mathrm{p}$.

Hasan, M. R. (2001). Nutrition and Feeding for Sustainable Aquaculture Development in the Third Millennium. In: Subasinghe, R.P., Bueno, P., Phillips, M.J., et al., Eds., Aquaculture in the Third Millennium. Technical Proceedings of the Conference on Aquaculture in the Third Millennium, Bangkok, Thailand, 20-25 February 2000. NACA, Bangkok and FAO, Rome, 193-219.

Heikkinen, J., Vielma, J., Kemiläinen, O., Tiirola, M., Eskelinen, P., Kiuru, T., Navia-Paldanius, D. \& Von Wright, A. (2006). Effects of soybean meal based diet on growth performance, gut histopathology and intestinal microbiota of juvenile rainbow trout (Oncorhynchus mykiss). Aquaculture, 261, $259-268$. https://doi.org/10.1016/j.aquaculture.2006.07.012

Henry, M. \& Fountoulaki, E. (2014). Optimal dietary protein/lipid ratio for improved immune status of a newly cultivated Mediterranean fish species, the shi drum Umbrina cirrosa, L. Fish \& Shellfish Immunology 37, 215-219. https://doi.org/10.1016/j.fsi.2014.02.005

Henry, M., Gasco, L., Piccolo, G. \& Fountoulaki, E. (2015). Review on the use of insects in the diet of farmed fish: past and future. Anim. Feed Sci. Technol. 203, 1-22. https://doi.org/10.1016/j.anifeedsci.2015.03.001

Henry, M. A., Gai, F., Enes, P., Peréz-Jiménez, A. \& Gasco, L. (2018a). Effect of partial dietary replacement of fishmeal by yellow mealworm (Tenebrio molitor) larvae meal on the innate immune response and intestinal antioxidant enzymes of rainbow trout (Oncorhynchus mykiss). Fish Shellfish Immunol. 83, 308-313. https://doi.org/10.1016/j.fsi.2018.09.040

Henry, M. A., Gasco, L., Chatzifotis, S. \& Piccolo, G. (2018b). Does dietary insect meal affect the fish immune system? The case of mealworm, Tenebrio molitor on European sea bass, Dicentrarchus labrax. Dev. Comp. Immunol. 81, 204-209. https://doi.org/10.1016/j.dci.2017.12.002

Hertrampf, J. W. \& Piedade-Pascual, F. (2000). Handbook on Ingredients for Aquaculture Feeds. Kluwer Academic Publishers, Dordrecht, The Netherlands. 
Hornung, B. (1991). The importance of mealworm larvae (Tenebrio molitor, L. 1758) as carriers of zearalenone when fed to insectivorous birds and other pet animals. In: Die Bedeutung der Larven des Mehlkafers (Tenebrio molitor, L. 1758) als Ubertrager von Zearalenon in der Futterung von insektivoren Vogeln und anderen Heimtieren. $81 \mathrm{pp}$.

Hua K. (2021). A meta-analysis of the effects of replacing fish meals with insect meals on growth performance of fish. Aquaculture 530, 735-732. https://doi.org/10.1016/j.aquaculture.2020.735732

Iaconisi, V., Marono, S., Parisi, G., Gasco, L., Genovese, L., Maricchiolo, G. \& Piccolo, G. (2017). Dietary inclusion of Tenebrio molitor larvae meal: Effects on growth performance and final quality treats of blackspot sea bream (Pagellus bogaraveo). Aquaculture 476, 49-58. http://dx.doi.org/10.1016/j.aquaculture.2017.04.007

Iaconisi, V., Bonelli, A., Pupino, R., Gai, F. \& Parisi, G. (2018). Mealworm as dietary protein source for rainbow trout: Body and fillet quality traits. Aquaculture 484, 197-204. https://doi.org/10.1016/j.aquaculture.2017.11.034

Iaconisi, V., Secci, G., Sabatino, G., Piccolo, G., Gasco, L., Papini, A.M. \& Parisi, G. (2019). Effect of mealworm (Tenebrio molitor L.) larvae meal on amino acid composition of gilthead sea bream (Sparus aurata L.) and rainbow trout (Oncorhynchus mykiss W.) fillets. Aquaculture $513,734403$. https://doi.org/10.1016/j.aquaculture.2019.734403

Ido, A., Hashizume, A., Ohta, T., Takahashi, T., Miura, C. \& Miura, T. (2019). Replacement of fish meal by defatted yellow mealworm (Tenebrio molitor) larvae in diet improves growth performance and disease resistance in red seabream (Pargus major). Animals 9 (3), 100. https://doi.org/10.3390/ani9030100

Ikeda, M., Miyauchi, K. \& Matsumiya, M. (2012). Purification and characterization of a $56 \mathrm{kDa}$ chitinase isozyme (PaChiB) from the stomach of silver croaker Pennahia argentatus. Biosci. Biotechnol. Biochem., 76, 971-979. https://doi.org/10.1271/bbb.110989

Ikeda, M., Shirase, D., Sato, T., Ueda, M., Hirabayashi, S. \& Matsumiya, M. (2014). Primary structure and enzymatic properties of chitinase isozymes purified from the stomach of the marbled rockfish Sebastiscus marmoratus. J. Chitin Chitosan Sci., 2, 106-116. https://doi.org/10.1166/jcc.2014.1048

IPIFF (2018). International Platform of Insects for Food and Feed (IPIFF). The European insect sector today: challenges, opportunities and regula tory landscape; IPIFF: Brussels, Belgium.

Iwasaki, A. \& Medzhitov, R. (2010). Regulation of adaptive immunity by the innate immune system. Science 327, 291-295. Doi: 10.1126/science.1183021

Janssen, R. H., Vincken, J. P., van den Broek, L. A., Fogliano, V. \& Lakemond, C. M. (2017). Nitrogen-to-protein conversion factors for three edible insects: Tenebrio molitor, Alphitobius diaperinus, and Hermetia illucens. J. Agric. Food Chem., 65, 2275-2278. Doi: 10.1021/acs.jafc.7b00471

Jeuniaux, C. (1993). Chitinolytic systems in the digestive tract of vertebrates: a review. Chitin Enzymol., 1, 233-244.

Józefiak, A., Nogales-Mérida, S., Rawski, M., Kierończyk, B. \& Mazurkiewicz, B. (2019). Effects of insect diets on the gastrointestinal tract health and growth performance of Siberian sturgeon (Acipenser baerii Brandt, 1869). BMC Veterinary Research 15, 348. https://doi.org/10.1186/s12917-019-2070-y

Junior, J. C. L., Ferreira, L. C. F. \& Pederiva, K. A. (2018). Development of Tenebrio molitor L. larvae in different diets aiming at the production of insects for human consumption. Conection online (2018) n.18, ISSN 1980-7341.

Khan, S., Naz., Sultan, A., Alhidary, I. A., Abdelrahman, M. M., Khan, R. U., Khan, N. A., Khan, M. A. \& Ahmad, S. (2016). Worm meal: a potential source of alternative protein in poultry feed. Poult. Sci. J., 72 (1), 93-102. https://dx.doi.org/10.1017/S0043933915002627

Khempaka, S., Chitsatchapong, C. \& Molee, W. (2011). Effect of chitin and protein constituents in shrimp head meal on growth performance, nutrient digestibility, intestinal microbial populations, volatile fatty acids, and ammonia production in broilers. J. Appl. Poult. Res., 20, 1-11. https://doi.org/10.3382/japr.2010-00162

Khosravi, S., Kim, E., Lee, Y-S \& Lee, S-M. (2018). Dietary inclusion of mealworm (Tenebrio molitor) meal as na alternative protein source in practical diets for juvenile rockfish (Sebastes schlegeli). Entomological Research 48, 214-221. https://doi.org/10.1111/1748-5967.12306

Kiron, V. (2012). Fish immune system and its nutritional modulation for preventive health care, Anim. Feed Sci. Technol. 173, 111-133. https://doi.org/10.1016/j.anifeedsci.2011.12.015

Klunder, H.C., Wolkers-Rooijackers, J., Korpela, J. M. \& Nout, M. J. (2012). Microbiological aspects of processing and storage of edible insects. Food Control 26:628-31.

König, E., Bininda-Emonds, R. P. \& Shaw, C. (2015). The diversity and evolution of anuran skin peptides. Peptides 63, 96-117. https://doi.org/10.1016/j.peptides.2014.11.003

Köprücü, K. \& Özdemir, Y. (2005). Apparent digestibility of selected feed ingredients for Nile tilapia (Oreochromis niloticus). Aquaculture 250, 308-316. https://doi.org/10.1016/j.aquaculture.2004.12.003

Kroeckel, S., Harjes, A. G. E., Roth, I., Katz, H., Wuertz, S., Susenbeth, A. \& Schulz, C. (2012). When a turbot catches a fly: evaluation of a pre-pupae meal of the Black Soldier Fly (Hermetia illucens) as fish meal substitute - growth performance and chitin degradation in juvenile turbot (Psetta maxima). Aquaculture, v. 364-365, 345-352. https://doi.org/10.1016/j.aquaculture.2012.08.041

Krogdahl, Å., Hemre, G. I. \& Mommsen, T. P. (2005). Carbohydrates in fish nutrition: Digestion and absorption in postlarval stages. Aquac. Nutr., 11, 103122.

Kurokawa, T., Uji, S. \& Suzuki, T. (2004). Molecular cloning of multiple chitinase genes in Japanese flounder Paralichthys olivaceus. Comp. Biochem. Physiol. B: Biochem. Mol. Biol., 138, 255-264. https://doi.org/10.1016/j.cbpc.2004.03.015

Kurtz, J. Kalbe, M., Aeschlimann, P. B., Haberli, M. A., Wegner, K. M., Reusch, T. B. H. \& Milinski, M. (2004). The diversity of the major histocompatibility complex influences the parasite resistance and innate immunity in sticklebacks. P. Roy. Soc. B-Biol. Sci., 271, pp. 197 - 204. 
https://doi.org/10.1098/rspb.2005.3450

Kus, M. M. \& Mancini-Filho, J. (2010). Fatty Acids: Eicosapentaenoic (EPA) and Docosahexaenoic (DHA). Series of Publications Ilsi Brasil: Fully Recognized Functions of Nutrients, vol. 17, p. 1-20.

Lee, C. G., Da Silva, C.A., Lee, J.-Y., Hartl, D. \& Elias, J.A. (2008). Chitin regulation of imune responses: an old molecule with new roles. Curr. Opin. Immunol. 20, 684-689. https://doi.org/10.1016/j.coi.2008.10.002

Lenaerts, S., Van Der Borght, M., Callens, A. \& Van Campenhout, L. (2018). Suitability of microwave drying for mealworms (Tenebrio molitor) as alternative to freeze drying: Impact on nutritional quality and colour. Food Chem., 254, 129-136. https://doi.org/10.1016/j.foodchem.2018.02.006

Li, F. W., Wang, W. L., Li, E. X., Li, S. Y. \& Liu, C. A. (2008). Analysis of fatty acids in Tenebrio molitor linneeus by GC-US. Food Research \& Development 29, 92-94.

Lie, Ø. (2001). Flesh quality - the role of nutrition. Aquaculture Research. 32, 341-348. https://doi.org/10.1046/j.1355-557x.2001.00026.x

Lin, D., Mao, Y. \& Cai, F. (1990). Nutritional lipid liver disease of grass carp Ctenopharyngodon idullus (C. et V.). Chin. J. Oceanol. Limn., 8, $363-373$.

Liu, W. X., Wei, M. C. \& Liu, G. Q. (2005). Bioactive compounds from insects and its development perspective. Food Sci. Technol. 1, 48-51.

Liu, Y. S., Wang, F. B., Cui, J. X. \& Zhang, L. (2010). Recent status and advances on study and utilization of Tenebrio molitor. Journal of Environmental Entomology 32, 106-114.

Loponte, R., Marono, S., Iaconisi, V., Piccolo, G., Parisi, G. \& Bovera, F. (2016). Caecal volatile fatty acid production of broilers fed Tenebrio molitor larvae meal. INSECTA 2016 International Symposium on Insects as Food, Feed and Non-Food, Magdeburg (Germany), 12th September 2016.

Magnadóttir, B. (1998). Comparison of immunoglobulin (IgM) from four fish species. Icel. Agr. Sci., 12, 47-59.

Maehre, H. K., Dalheim, L., Edvinsen, G. K., Elvevoll, E. O. \& Jensen, I. J. (2018). Protein determination - method matters. Foods 7(1), 5. https://doi.org/10.3390/foods7010005

Makkar, H. P. S., Tran, G., Heuzé, V. \& Ankers, P. (2014). Rewiew: State-of-the-art on use of insects as animal feed. Anim. Feed Sci. Technol., 197, 1-33. https://doi.org/10.1016/j.anifeedsci.2014.07.008

Marono, S., Piccolo, G., Loponte, R., Di Meo, C., Attia, Y. A., Nizza, A. \& Bovera, F. (2015). In vitro crude protein digestibility of Tenebrio molitor and Hermetia illucens insect meals and its correlation with chemical composition traits. Ital. J. Anim. Sci. 14, 3889. https://doi.org/10.4081/ijas.2015.3889

Megido, R. C., Desmedt, S., Blecker, C., Béra, F., Haubruge, E., Alabi, T. \& Francis, F. (2017). Microbiological load of edible insects found in Belgium. Insects 8:12.

Menezes, M. E. S., Lira, G. M., Omena, C. M. B., Freitas, J. D. \& Sant'Ana, A. E. G. (2009). Nutritive values of fishes from maritime coast of Alagoas, Brazil. Rev. Inst. Adolfo Lutz (Impr.) [online], vol.68, n.1 [citado 2021-08-11], pp. 21-28.

Menezes, C. W. G., Camilo, S. S., Fonseca, A. J., Júnior, S. L. A., Bispo, D. F. \& Soares, M. A. (2014). Can the diet of the prey Tenebrio molitor (Coleoptera: Tenebrionidae) affect the development of the predator Podisus nigrispinus (Heteroptera: Pentatomidae)? Arq. Inst. Biol., 81, 3, $250-256$. https://doi.org/10.1590/1808-1657001212012

Mohieldein, A., Hyder, M. A. \& Hasan, M. (2013). Comparative levels of ALT, AST, ALP and GGT in liver associated diseases. Eur. J. Exp. Biol., 3 (2), 280284.

Mroz, Z. (2005). Organic acids as potential alternatives to antibiotic growth promoters for pigs. Adv. Pork Prod. 16, 169-182.

Munshi J. S. D. \& Dutta H. M. (1996). Fish Morphology: Horizon of New Research. Science Publishers, 300p.

Nascimento, A. C., Fontes, W., Sebben, A. \& Castro, M. S. (2003). Antimicrobial peptides from anurans skin secretions. Protein Pept Lett., 10 (3), $227-238$.

Navarre, W. W. \& Schneewind, O. (1999). Surface proteins of gram-positive bacteria and mechanisms of their targeting to the cell wall envelope. Microbiol.Mol. Biol. Rev. 63, 174-229.

Nawrocki, K. L., Crispell, E. K. \& McBride, S. M. (2014). Antimicrobial peptide resistance mechanisms of Gram-positive bacteria. Antibiotics, 3 (4), 461 492. https://doi.org/10.3390/antibiotics3040461

New, M. B. \& Wijkstroem, U. N. (2002). Use of Fishmeal and Fish Oil in Aquafeeds: Further Thoughts on the Fishmeal Trap. FAO Fisheries Circular No. 975.

Ngo, D. H. \& Kim, S. K. (2014). Antioxidant effects of chitin, chitosan, and their derivatives. Adv. Food Nutr. Res. 73, 15-31. https://doi.org/10.1016/B978-0$12-800268-1.00002-0$

NRC (2011). Nutrient Requirements of Fish and Shrimp, 1st ed. (Washington, DC, USA).

OECD/FAO (2019). OECD-FAO Agricultural Outlook 2019-2028, OECD Publishing, Paris/Food and Agriculture Organization of the United Nations, Rome. https://doi.org/10.1787/agr_outlook-2019-en

Parra, J. R. P. (2009). The evolution of artificial diets and their interactions in science and technology. In: Panizzi, A.R. \& Parra, J.P.R. (Ed). Insect bioecology and nutrition: basis for integrated pest management. Embrapa: Brasília, p.91-174.

Piccolo, G., Marono, S., Gasco, L., Iannaccone, F., Bovera, F. \& Nizza, A. (2014). Use of Tenebrio molitor larvae meal in diets for Gilthead seabream (Sparus 
aurata) juveniles. Insects to Feed The World (p. 76). The Netherlands: Wageningen University.

Piccolo,G., Iaconisi,V., Marono, S., Gasco, L., Loponte, R., Nizza, S., Bovera, F. \& Parisi, G. (2017). Effect of Tenebrio molitor larvae meal on growth performance, in vivo nutrients digestibility, somatic and marketable indexes of gilthead sea bream (Sparus aurata). Animal Feed Science and Technology, 226, 12-20. https://doi.org/10.1016/j.anifeedsci.2017.02.007

Ramos-Elorduy, J., González, E.A., Hernández, A. R. \& Pino, J. M. (2002). Use of Tenebrio molitor (Coleoptera: Tenebrionidae) to recycle organic wastes and as feed for broiler chickens. J. Econ. Entomol. 95 (1), 214-220. https://doi.org/10.1603/0022-0493-95.1.214

Ramos Filho, M. M., Ramos, M. I. L., Hiane, P. A. \& Souza, E. M. T. (2008). Perfi lipídico de quatro espécies de peixes da região pantaneira de Mato Grosso do Sul. Ciênc. Tecnol. Aliment., Campinas., 28(2): 361-5

Rauta, P. R., Nayak, B. \& Das, S. (2012). Immune system and immune responses in fish and their role in comparative immunity study: a model for higher organisms. Immunol. Lett. 148 (1), 23-33. https://doi.org/10.1016/j.imlet.2012.08.003

Rema, P., Saravanan, S., Armenjon, B, Motte, C. \& Dias, J. (2019). Graded incorporation of defatted yellow mealworm (Tenebrio molitor) in rainbow Trout (Oncorhynchus mykiss) diet improves growth performance and nutrient retention. Animals, 9, 187. doi:10.3390/ani9040187

Ribeiro, G.O. (2019). Flour from the larvae of Tenebrio molitor in the feeding of Nile tilapia. Thesis (Master's degree). Postgraduate Program in Animal Science, State University of Montes Claros (Unimontes), Minas Gerais, MG.

Ringø, E., Zhou, Z., Vecino, J. L. G., Wadsworth, S., Romero, J., Krogdahl, Å., Olsen, R. E., Dimitroglou, A., Foey, A., Davies, S., Owen, M., Lauzon, H. L., Martinsen, P., De Schryver, P., Bossier, P., Sperstad, S. \& Merrifield, D. L. (2015). Effect of dietary components on the gut microbiota of aquatic animals. A never- ending story? Aquaculture Nutrition 22, 219-282. http://dx.doi.org/10.1111/anu.12346

Rumpold, B. A. \& Schlüter, O. K. (2013). Potential and challenges of insects as an innovative source for food and feed production. Innov. Food Sci. Emerg. Technol. 17, 1-11. https://doi.org/10.1016/j.ifset.2012.11.005

Sakai, M., Kamiya, H., Ishii, S., Atsuta, S. \& Kobayashi, M. (1992). The immunostimulating effects of chitin in rainbow trout, Oncorhynchus mykiss. Dis. Asian Aquacult., 1, 413-417.

Sales, J. \& Janssens, G. P. J. (2003). Nutrient requirements of ornamental fish. Aquat. Living Resour. 16, 533-540. Doi:10.1016/j.aquliv.2003.06.001

Sánchez, T. C. I. \& Burgos, Y. V. (2014). Determination of anthocyanins and nutritional value of tenebrios (Tenebrio molitor) fed with diets enriched with maize maize (Zea mays L.). Course Conclusion Paper (Biotechnology Engineering of Natural Resources). Universidad Politécnica Salesiana Sede Quito Quito, Ecuador.

Sánchez-Muros, M.J., Barroso, F. G. \& Manzano-Agugliaro, F. (2014). Insect meal as renewable source of food for animal feeding: a review. J. Clean. Prod. $65,16-27$.

Sánchez-Muros, J., de Haro, C., Sanz, A., Trenzado, C. E., Villareces, S. \& Barroso, F. G. (2015). Nutritional evaluation of Tenebrio molitor meal as fishmeal substitute for tilapia (Oreochromis niloticus) diet. Aquaculture Nutrition 22, 943-955.

Sankian, Z., Khosravi, S., Kim, Y-O. \& Lee, S-M. (2018). Effects of dietary inclusion of yellow mealworm (Tenebrio molitor) meal on growth performance, feed utilization, body composition, plasma biochemical indices, selected immune parameters and antioxidant enzyme activities of mandarin fish (Siniperca scherzeri) juveniles. Aquaculture 496, 79-87. https://doi.org/10.1016/j.aquaculture.2018.07.012

Saurabh, S. \& Sahoo, P. K. (2008). Lysozyme: an important defence molecule of fish innate immune system. Aquac. Res., 39, 223-239.

Sealey, W. M., Gaylord, T. G., Barrows, F. T., Tomberlin, J. K., McGuire, M. A., Ross, C. \& St-Hilaire, S. (2011). Sensory analysis of rainbow trout, Oncorhynchus mykiss, fed enriched Black Soldier Fly prepupae, Hermetia illucens. J. World Aquacult. Soc. 42, 34-45. https://doi.org/10.1111/j.17497345.2010.00441.x

Skalli, A. \& Robin, J. H. (2004). Requirement of n-3 long chain polyunsaturated fatty acids for European sea bass (Dicentrarchus labrax) juveniles: growth andfatty acid composition. Aquaculture 240, 399-415, http://dx.doi.org/10.1016/j. aquaculture.2004.06.036.

Song, S. G., Chi, S. Y., Tan, B. P., Liang, G. L., Lu, B. Q., Dong, X. H., Yang, Q. H., Liu, H. Y \& Zhang, S. (2018). Effects of fishmeal replacement by Tenebrio molitor meal on growth performance, antioxidante enzyme activities and disease resistance of the juvenile pearl gentian grouper (Epinephelus lanceolatus x Epinephelus fuscoguttatus). Aquaculture Research, 49, 2210-2217. https://doi.org/10.1111/are.13677

Souza, P. C. \& Teles, B. R. (2011). Life cycle of Tenebrio molitor (Coleoptera) larvae, under different diets. IN: Proceedings of the XX Scientific Initiation Day PIBIC INPA - CNPq / FAPEAM, Manaus.

Spang, B. (2013). Insects as food: assessing the food conversion efficiency of the mealworm (Tenebrio Molitor). Environmental study master thesis: The Evergreen State College.

Sperandio LM. A Importância do Peixe na Alimentação Humana. GO. Disponível em <http://www.setorpesqueiro.com.br/portal. asp.

Stansby, M. E. (1973). Polynsaturates and fat in fi sh fl esh. J. Am. Diet. Ass., 63: 625-30.

St-Hilaire, S., Sheppard, C., Tomberlin, J. K., Irving, S., Newton, L., McGuire M. A., Mosley, E. E., Hardy, E. E., Hardy, R. W. \& Sealey, W. (2007). Fly prepupae as a feedstuff for rainbow trout, Oncorhynchus mykiss. J. World Aquacult. Soc. 38, 59-67. https://doi.org/10.1111/j.1749-7345.2006.00073.x

Su, J., Gong, Y., Cao, S., Lu, F., Han, D., Liu, H., Jin, J., Yang, Y., Zhu, X. \& Xie, S. (2017). Effects of dietary Tenebrio molitor meal on the growth performance, immune response and disease resistance of yellow catfish (Pelteobagrus fulvidraco). Fish Shellfish Imm., $69,59-66$. https://doi.org/10.1016/j.fsi.2017.08.008 
Superior Health Council (2014). Food safety aspects of insects intended for human consumption. Scientific Committee of the Federal Agency for the safety of food Chain, 9160, 1-23.

Tacon, A. G. J., Hasan, M. R., Allan, G., El-Sayed, A. -F., Jackson, A., Kaushik, S. J., Ng, W-K., Suresh, V. \& Viana, M. T. (2012). Aquaculture feeds: addressing the longterm sustainability of the sector. In: Subasinghe, R. P., Arthur, J. R., Bartley, D. M., De Silva, S. S., Halwart, M., Hishamunda, N., Mohan., C. V \& Sorgeloos, P. Eds. Farming the Waters for People and Food. Proceedings of the Global Conference on Aquaculture 2010, Phuket, Thailand. 22-25 September 2010. pp. 193-231. FAO, Rome and NACA, Bangkok.

Teh, S.-S., Bekhit, A.E.-D., Carne, A. \& Birch, J. (2013). Effect of the defatting process, acid and alkali extraction on the physicochemical and functional properties of hemp, flax and canola seed cake protein isolates. J. Food Measure. Charact., 8 (2013), pp. 92-104, 10.1007/s11694-013-9168-x

Tharanathan, R. N. \& Kittur, F. S. (2003). Chitin - The undisputed biomolecule of great potential. Crit. Rev. Food Sci. Nutr., 43 , $61-87$.

Tibaldi, E., Zittelli, G. C., Parisi, G., Bruno, M., Giorgi, G., Tulli, F., Venturini, S., Tredici, M. R. \& Poli, B. M. (2015). Growth performance and quality traits of European sea bass (D. labrax) fed diets including increasing levels of freeze-dried Isochrysis sp. (T-ISO) biomass as a source of protein and n-3 long chain PUFA in partial substitution of fish derivatives. Aquaculture 440, 60-68. https://doi.org/10.1016/j.aquaculture.2015.02.002

Tubin, J. S. B., Paiano, D., Hashimotob, G. S. O., Furtado, W. E., Martins, M. L, Durigon, E. \& Emerenciano, M. G. C. (2020). Tenebrio molitor meal in diets for Nile tilapia juveniles reared in biofloc system. Aquaculture 519, 734-763. https://doi.org/10.1016/j.aquaculture.2019.734763

United Soybean Board (2019). Supply \& Disappearance. USB Market View Database (n.d.). Available at: https://marketviewdb.centrec.com/sd/. (Accessed: 2nd August 2020)

van Broekhoven, S., Oonincx, D. G. A. B., van Huis, A., van Loon, J. J. A. (2015) Growth performance and feed conversion efficiency of three edible mealworm species (Coleoptera: Tenebrionidae) on diets composed of organic by-products J. Insect Physiol. 73, 1-10. https://doi.org/10.1016/j.jinsphys.2014.12.005

Veldkamp, T., van Duinkerken, G., van Huis, A., Lakemond, C. M. M, Ottevanger, E., Bosch, G. \& van Boekel, T. (2012). Insects as a sustainable feed ingredient in pig and poultry diets: a feasibility study. Wageningen UR Livestock Production, report 638, p.1-48.

Veldkamp, T. \& Bosch, G. (2015). Insects: um ingrediente rico em proteínas na dieta de suínos e aves. Anim Front., 5: 45-50.

Vilella, L. M. (2018). Production of insects for use in animal feed. Course Conclusion Paper (Zootechnics), Faculty of Agronomy, Federal University of Rio Grande do Sul (UFRGS), Porto Alegre, RS.

Zasloff, M. (2002). Antimicrobial peptides of multicellular organisms. Nature 415, 389-395.

Zoccarato, I., Benatti, G., Bianchini, M. L., Boccignogne, M., Conti, A., Napolitano, R. \& Palmegiano, G. B. (1994). Differences in performances, flesh composition and water output quality in relation to density and feeding levels in rainbow trout Oncorhynchus mykiss (Walbaum) farming. Aquac. Fish. Manag. 25, 639-647. https://doi.org/10.1111/j.1365-2109.1994.tb00728.x

Zhu, L-Y., Nie, L., Zhu, G., Xiang, L-X. \& Shao, J-Z. (2013). Advances in research of fish immune-relevant genes: a comparative overview of innate and adaptive immunity in teleosts. Dev. Comp. Immunol. 39, 39-62. https://doi.org/10.1016/j.dci.2012.04.001 